University of Arkansas, Fayetteville

ScholarWorks@UARK

Graduate Theses and Dissertations

$12-2018$

\title{
Changes to Subaqueous Delta Bathymetry Following a High River Flow Event, Wax Lake Delta, USA
}

Amanda Rose Whaling

University of Arkansas, Fayetteville

Follow this and additional works at: https://scholarworks.uark.edu/etd

Part of the Geomorphology Commons, Geophysics and Seismology Commons, and the Sedimentology Commons

\section{Citation}

Whaling, A. R. (2018). Changes to Subaqueous Delta Bathymetry Following a High River Flow Event, Wax Lake Delta, USA. Graduate Theses and Dissertations Retrieved from https://scholarworks.uark.edu/etd/ 3044

This Thesis is brought to you for free and open access by ScholarWorks@UARK. It has been accepted for inclusion in Graduate Theses and Dissertations by an authorized administrator of ScholarWorks@UARK. For more information, please contact scholar@uark.edu. 
Changes to Subaqueous Delta Bathymetry Following a High River Flow Event, Wax Lake Delta, USA

\begin{abstract}
A thesis submitted in partial fulfillment of the requirements for the degree of Master of Science in Geosciences
\end{abstract}

by

Amanda Whaling

Indiana University

Bachelor of Science in Geology, 2016

December 2018

University of Arkansas

This thesis is approved for recommendation to the Graduate Council.

John Shaw, Ph.D.

Thesis Director

Steve Boss, Ph.D.

Committee Member

Glenn Sharman, Ph.D.

Committee Member
Jackson Cothren, Ph.D.

Committee Member

Daniel Wagner, M.S.

Committee Member 


\begin{abstract}
I report changes to the subaqueous bathymetry of the Wax Lake Delta (WLD) located in coastal
\end{abstract} Louisiana with the purpose of quantifying the two- and three-dimensional evolution of the entire delta front. The spatial distribution and volume of erosion and deposition were determined by differencing two Digital Elevation Models (DEMs) collected 16 months apart, including the $2^{\text {nd }}$ largest high flow event (flood) in the WLD's recorded history. The difference map showed $6.41 \times 10^{6} \mathrm{~m}^{3} \pm 3.70 \%$ of sediment were deposited and $1.19 \times 10^{7} \mathrm{~m}^{3} \pm 2.71 \%$ were eroded yielding $5.46 \times 10^{6} \mathrm{~m}^{3} \pm 7.32 \%$ of net erosion in the survey area $\left(\sim 75.9 \mathrm{~km}^{2}\right)$. Generally, deposition on the delta front was spatially localized around channels and the delta flanks whereas erosion was spatially uniform. The widespread erosional signature was likely associated with sediment resuspension and export out of the survey area during winter cold fronts, with minor influences from shallow subsidence and tides. Despite the occurrence of a significant flood during the survey period, I conclude that subaqueous delta growth is less influenced by the flood cycle than more proximal subaerial islands. Floods do, however, act to increase channel network asymmetry by aggrading a majority of channels and incising a few. I attempted to test if the distribution of flow between distributary channels scales with the distribution of net deposition in a channel's respective nourishment area, the space that receives water and sediment from a given channel. A majority of nourishment areas were net-erosional which violated a central assumption about the hypothesis. I conclude that deposition within a nourishment area cannot be predicted from discharge alone. The field data presented here suggests that models of deltaic growth need to account for significant volume export from the delta front. Given that the subaqueous delta was net erosional, delta retrogradation is possible over short timescales in an environment that is progradational overall. Thus, future models should also introduce annual variability in growth rates to better predict the decadal growth of the WLD. Improvement of the predictive models of 
subaqueous WLD growth have important implications to land building from sediment diversions and stratigraphic analysis of deltas. 
C2018 by Amanda Whaling All Rights Reserved 


\section{Acknowledgements}

I gratefully acknowledge University of Arkansas faculty and students for their support and guidance; the members of my thesis committee for their highly valuable and insightful criticism that helped this work grow; Dan Wagner for sharing his scientific and technical expertise; and most importantly, my thesis adviser, John Shaw, for his enthusiasm for geoscience and thoughtful encouragement and supervision.

I also extend my gratitude to the University of Arkansas Department of Geosciences and John Shaw, awardee of the ACS PRF Doctoral New Investigator Grant and DOE Early Career Grant, through which this research was funded. 


\section{Dedication}

To my parents, Wanda and Timothy, without whom none of my success would be possible. 


\section{Table of Contents}

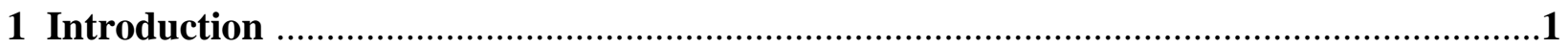

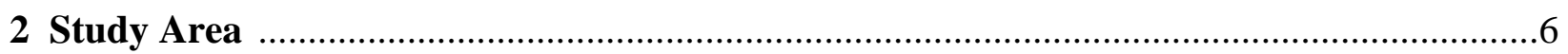

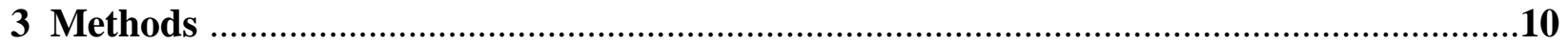

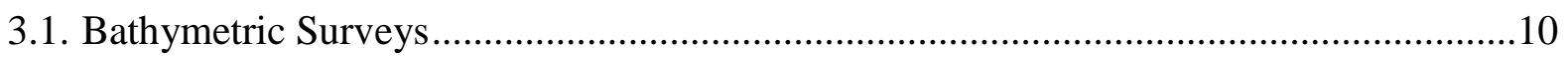

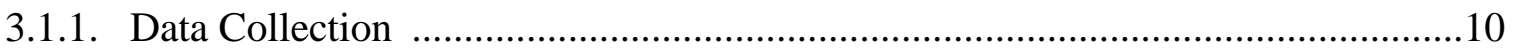

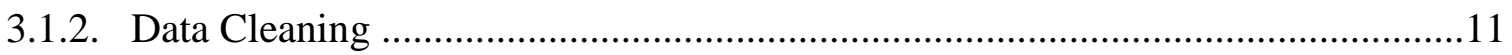

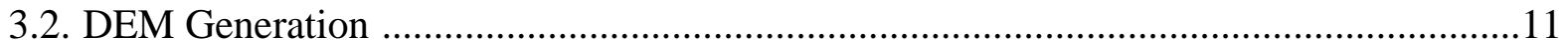

3.3. Volume of Suspended Sediment Delivered ………................................................14

3.4. Nourishment Boundaries and Flow Partitioning ........................................................

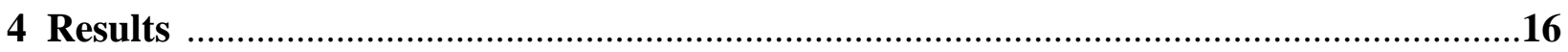

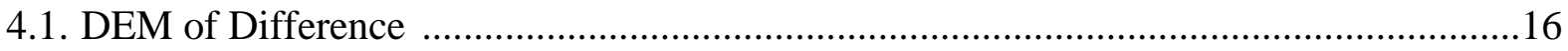

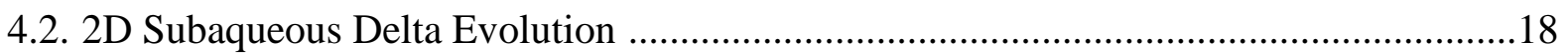

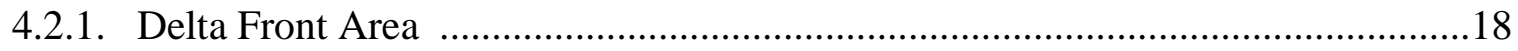

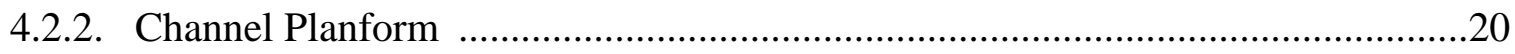

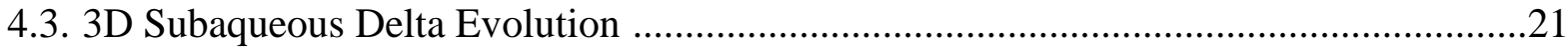

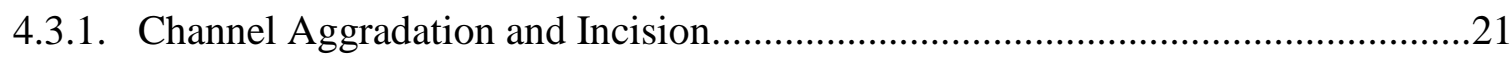

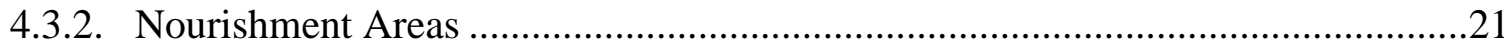

4.4. Flow Partitioning and Volume of Suspended Sediment Delivered ................................22

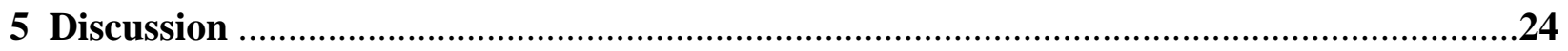

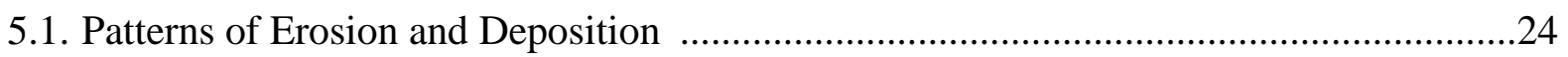

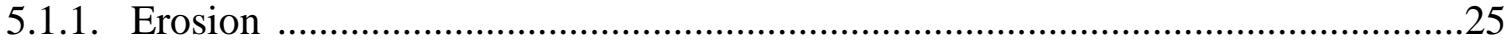

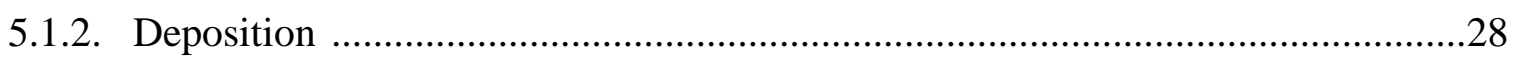

5.2. Effect of a Flood on Changing Subaqueous Delta Bathymetry .......................................30

5.3. Model for Subaqueous Delta Growth from Discharge to a Nourishment Area ................31

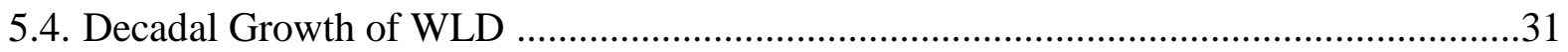

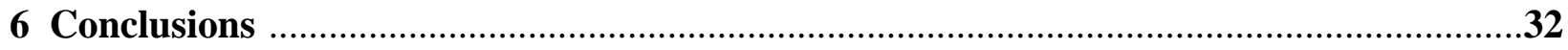

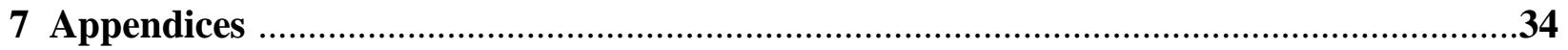

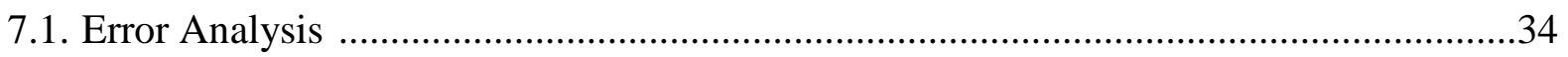

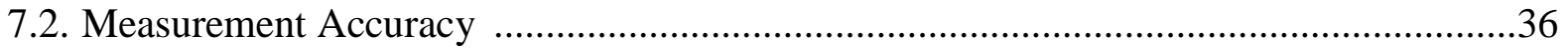

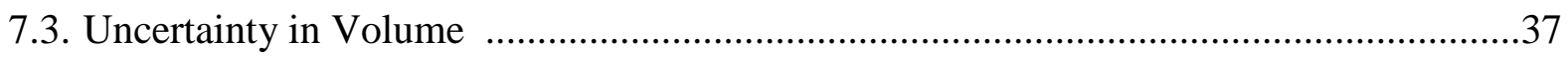

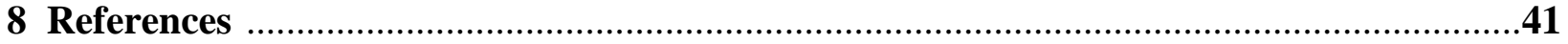




\section{Introduction}

The Wax Lake Delta (WLD) is an actively prograding sub-delta of the greater Mississippi River Delta that is $\sim 100 \mathrm{~km}^{2}$ in size located in coastal Louisiana, USA (Figure 1A-B). The WLD has been the focus of numerous studies aimed at understanding river delta evolution, morphology, and sustainability due to its rapid progradation in the last 40 years. Deltaic growth is often quantified in terms of subaerial land exposure (Allen, Couvillion, \& Barras, 2012; Olliver \& Edmonds, 2017; Roberts, Adams, \& Cunningham, 1980; Rosen \& Xu, 2013) but much less is known about subaqueous delta growth. Moreover, deltaic growth studies are often limited to measuring change in two dimensions. Two-dimensional change cannot be easily related to volumetric change which limits the predictive ability of deltaic growth models. It is the primary goal of this study to describe the 3D evolution of the subaqueous portion of the WLD by measuring the bathymetric change that occurred to the entire delta front over a $\sim 1$ year period. The bathymetric change was determined by differencing two Digital Elevation Models (DEMs) of the subaqueous portion of the WLD from February 2015 and July 2016. The unique data presented here allows me to define and investigate three corollary objectives of subaqueous delta evolution that were previously unknown. I seek to resolve 1) how a flood changes the subaqueous delta bathymetry 2) if the subaqueous evolution can be modeled by discharge to a nourishment area alone and 3) how bathymetric change measured over quasi-annual timescales compares to the decadal growth of the WLD. The assessment of the subaqueous delta growth over a short temporal interval presented here will contribute to our understanding of how river delta evolution occurs as a whole which will ultimately aid in land building from sediment diversions and stratigraphic analysis of deltas (Kim, Mohrig, Twiley, Paola, \& Parker, 2011; Shields et al., 2017). 
The survey period captured the second largest flood in the WLD's recorded history. Hence, this field study will be the first to document the effect a flood has on changing subaqueous delta bathymetry over the entire delta front. Floods have been shown to be positively correlated with subaerial delta growth (Bevington, Twilley, Sasser, \& Holm, 2017; Carle, Sasser, \& Roberts, 2013; Roberts et al., 1980; Rosen \& Xu, 2013). Roberts et al., 1980 attributes the sudden emergence and growth of the subaerial portion of the WLD and Atchafalaya Delta to a flood between 1973 and 1975 and argue that subaerial and subaqueous accretion is closely related to the flood cycle. They conclude that high flows, particularly those with high suspended sand concentration, are responsible for deltaic growth. Similarly, Bevington et al., 2017 concluded that increased sediment delivery during floods is associated with subaerial delta accretion in their study on the effect of seasonal forcings (floods, hurricanes, winter cold front passages). They found that the greatest contribution to net elevation gain was from floods, especially those with lower peak discharge but longer duration. Consistent with these observations are numerical model results that show distributary network evolution in a river dominated system via river mouth bar deposition simulated at bankfull discharge (Edmonds \& Slingerland, R. L., 2007). Provided that flood events are rarely measured on the field scale deltaic setting, these results provide new insight into understanding how floods impact subaqueous delta bathymetry.

Clearly, floods are expressed as net-depositional events on delta tops and they grow subaerially during floods therefore I might expect the delta front to be net-depositional and progradational in this study. A previous bathymetric change study conducted by Shaw \& Mohrig, 2014 revealed net-deposition on Gadwall Pass, one of seven main distributary passes on the WLD, following a flood period in 2011 (Figure 1C). Deposition was focused on the channel bed causing channel bed aggradation. During the same survey period, erosion was focused at channel sidewalls and at the 
sand shoals that separate distributary channels causing channel reorganization into a primary channel. During a low flow period beginning in 2010 and ending in 2011, erosion was focused on the channel bed and distributary tips causing channel bed degradation and bay-ward channel extension. The findings of Shaw \& Mohrig, 2014 demonstrate that erosion during floods and low flow events is necessary to explain the present morphology and growth of the delta front.

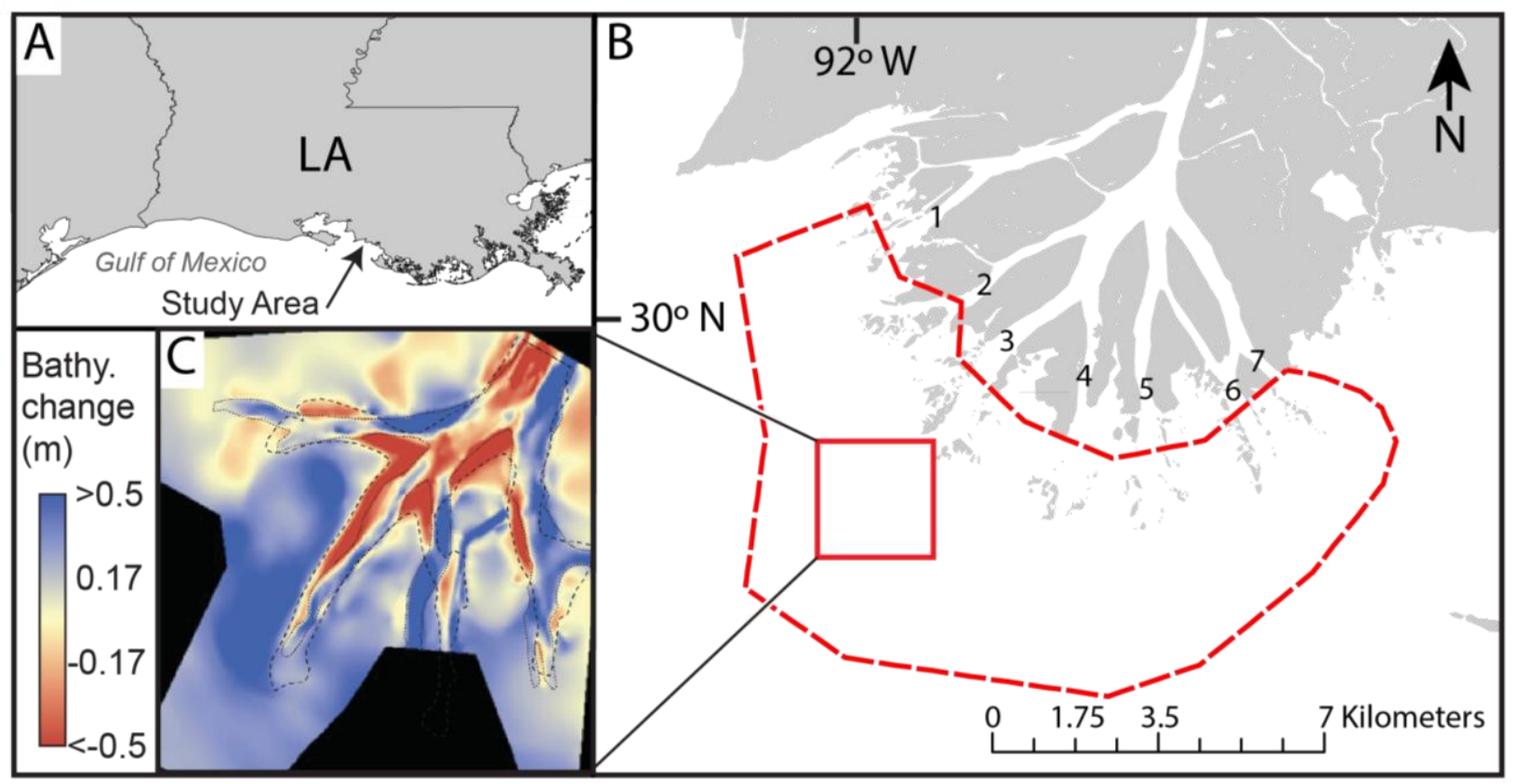

Figure 1. A) Study area. The WLD is located in coastal Louisiana, USA. B) Approximate subaerial extent of the WLD (gray) derived from LANDSAT 8 imagery acquired on 8 June 2016. The dashed red line shows the boundary of the subaqueous extent of the WLD that was surveyed. The solid red box shows the location of repeat bathymetric surveys of Gadwall Pass, one of 7 distributary passes on the WLD $(1=$ Campground, $2=$ Mallard, $3=$ Gadwall, $4=$ Main, $5=$ Greg, $6=$ Pintail, 7 = East). C) Changes to subaqueous bathymetry of Gadwall Pass. Shaw \& Mohrig, 2014 found that Gadwall Pass was characterized by net-deposition (blue) between March and August 2011 following a flood. I seek to determine if 1) all subaqueous channels and nourishment areas on the WLD evolve similarly or not over a $\sim 1$ year interval and if 2) the entire delta front is characterized by net-deposition following a significant flood. 
The second objective outlined above follows from the hypothesis that net deposition within a nourishment area, the space that receives water and sediment from a distributary channel, scales with discharge to that nourishment area. I have quantified the three-dimensional change to the delta front therefore I have the ability to answer this question by dividing the study area into nourishment areas and determining the volume of net deposition in each nourishment area. Though the spatial distribution of deposition is difficult to predict, there is little work that suggests whether or not it should be uniform across the delta front. I do however know that flow is nonuniformly distributed between distributary channels from a study of river deltas; namely, it was predicted that $20 \%$ of channels carry close to $50 \%$ of the total sediment flux (Edmonds, Paola, Hoyal, \& Sheets, 2011). A non-uniform distribution of flow has been verified on the WLD from discharge estimates from channel width (Edmonds et al., 2011) as well as from discharge measurements from a flow partitioning study conducted in 2012 (M. R. Hiatt, 2013). In both studies, it was shown that Gadwall Pass carries a larger portion of the total flow to the delta front compared to East, Pintail, Greg, Main, Campground, and Mallard Passes. If the volume of deposition in a nourishment scales with the nourishment area's input sediment flux, I could predict that the magnitude of deposition will be greatest in Gadwall Pass.

Finally, the third objective follows from the observation that integrating area change over short timescales (1 to 5 years) can result in growth rates drastically different than integrating over decadal timescales in previous studies of the WLD (Allen et al., 2012; Olliver \& Edmonds, 2017; Shaw, Estep, Whaling, Sanks, \& Edmonds, 2018). Allen et al., 2012 used time, water discharge, and tide level to determine the growth rate of the subaerially exposed delta from satellite imagery between 1983 and 2010. While the linear regression revealed that the delta grew $1 \mathrm{~km}^{2} / \mathrm{yr}$ over this time period, measurements between images approximately 1 year apart or less revealed 
extremely positive and negative growth rates. Similarly, (Olliver \& Edmonds, 2017) classified satellite imagery into land-cover classes at minimum and maximum biomass classes in order to analyze inter- and intra-annual land cover change and deltaic growth. Their method is not as sensitive to tides, floods, and storm surges which can inundate the vegation used as a proxy for land in the classified satellite imagery. Still, negative land growth rates were estimated in their study, but not as rapid as those estimated by Allen et al., 2012. Shaw et al., 2018 tracked the growth of the subaqueous platform by using a method that identifies the location of subaqueous channel tips in satellite imagery between 1974 and 2016. They found that the subaqueous platform grew $1.72 \mathrm{~km}^{2} / \mathrm{yr}$ and also observed negative growth rates between some of the images. Without field data, it is unknown if negative deltaic growth rates measured over quasi-annual timescales in these studies is associated with measurement error; it is possible that growth rates measured over short timescales differs drastically from the decadal average and these changes are readily observable on the WLD. This is demonstrated by the bathymetric change study of Gadwall Pass between July 2010 and February 2012 which saw both net erosion and deposition between repeat surveys as well as channel back-stepping greater than double its channel width (Shaw \& Mohrig, 2014). Although I cannot directly compare my results to the subaerial change during the same survey time period here, this study has the potential to explain the variability in previously measured subaerial and subaqueous growth rates of the WLD.

In this paper, I begin with a brief description of the study area followed by a description of the flow regime observed during the study period. I then describe the methods for collecting bathymetric data, creating the DEM and DEM of Difference (DoD), defining nourishment area boundaries, and calculating flow and sediment partitions to each distributary pass. I report the two- and three- dimensional changes that occurred to the delta front in the results section as well 
as a summary of the DoD statistics. In the discussion section I characterize the patterns of erosion and deposition. I assess various mechanisms that could have contributed to the patterns of erosion and deposition including the significant flood event during the survey period, waves, tides. The effect of subsidence in the survey area is also discussed. I also assess the efficacy of the model for subaqueous delta evolution using discharge to a nourishment area. Finally, I compare the subaqueous delta growth I measured to the decadal growth of the WLD. Error and uncertainty calculations associated with the DoD can be found in the Appendix.

\section{Study Area}

The WLD is fed by the Wax Lake Feeder Channel (WLFC) which receives flow from the Atchafalaya River, a bifurcation of the Mississippi River (Figure 2). The WLFC was dredged between 1938 and 1941 to divert flow from the Atchafalaya River to Atchafalaya Bay after flooding threatened urbanized areas along the Lower Atchafalaya River (Mossa, 2016). It was not until 1972 that the first subaerial delta deposits appeared at the Wax Lake Outlet and at the Atchafalaya River Outlet, eventually forming the modern WLD and Atchafalaya Delta, respectively. Subaerial delta growth was initially limited by an under-filled Atchafalaya Basin as well as large, under-filled lakes connecting stretches of the Atchafalaya River (Roberts et al., 1980). Since the early 70's, the Wax Lake Delta has added an impressive $38.5 \mathrm{~km}^{2}$ of subaerially exposed land to the Louisiana coast (Allen et al., 2012). The WLD demonstrates a significant amount of land can be built in a relatively short period of time thus it is often cited in support of engineered avulsions to combat relative sea level rise in sediment under-nourished areas of the Louisiana coast (Kim et al., 2011). 


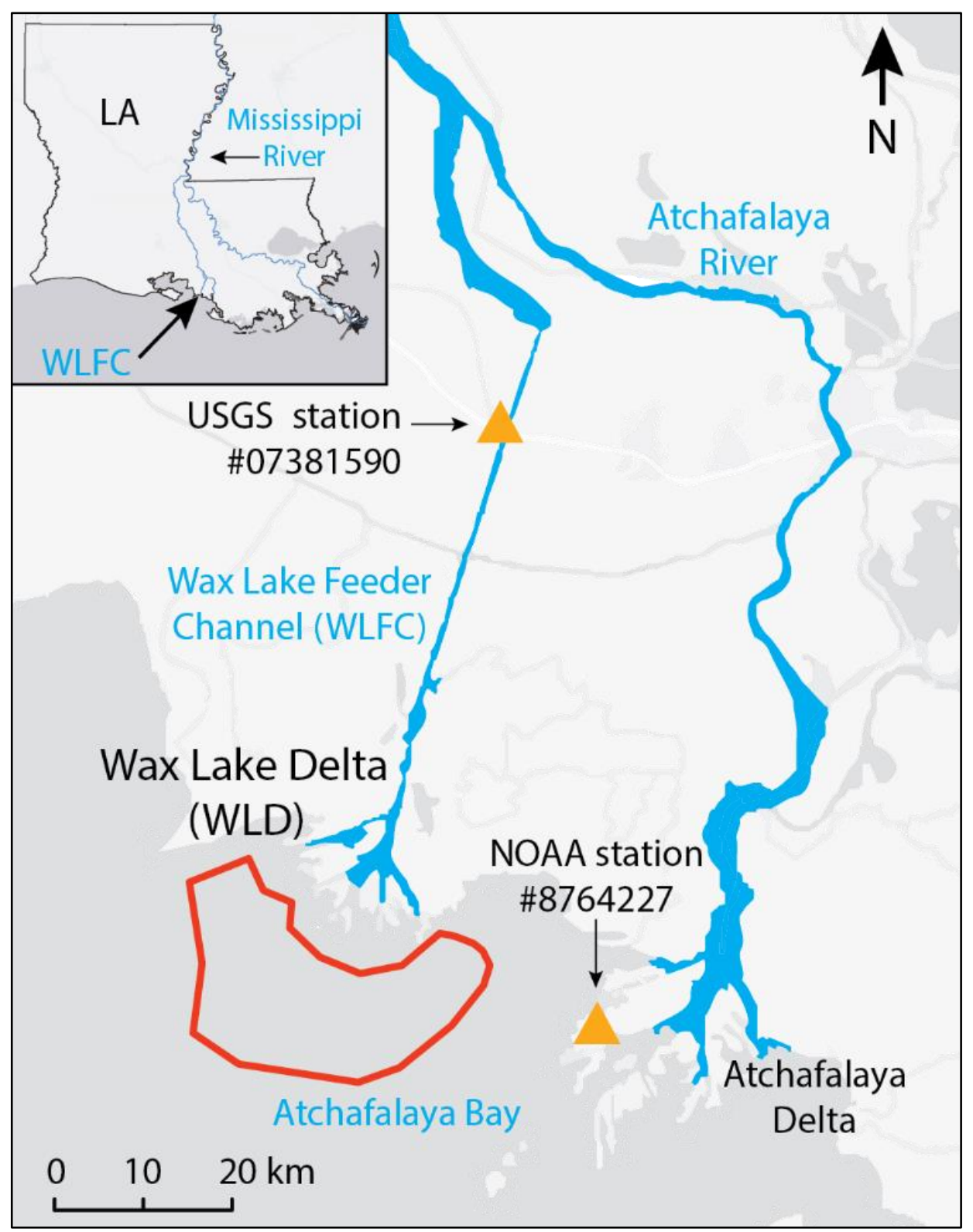

Figure 2. Detailed Study Area. The WLD is fed by the Wax Lake Feeder Channel (WLFC) which was dredged in the 1930s and 40s to reduce flooding along the Atchafalaya River, a bifurcation of the Mississippi River. The Wax Lake Delta has been building into Atchafalaya Bay since the early 70s. Discharge and tide data used in this study were aquired from USGS station \#07381590 on the WLFC and NOAA station \#8764227 on the neighboring Atchafalaya Delta. The red line shows the boundary of the subaqueous extent of the WLD that was surveyed. 
Floods occur annually on the WLD yet it is unknown how these events impact subaqueous delta bathymetry and growth. Floods, or high flow events, are generally quantified based on a timeaveraged characteristic discharge over an available dataset acquired at a constant location. For example, Roberts et al., 1980 defined high flow as any mean monthly discharge that exceeded the average annual flow which was $11,000 \mathrm{~m}^{3} / \mathrm{s}$ for the time period between 1956 and 1975 measured at Simmesport, LA. In this study, I define high flow as discharges greater than the 15-year median daily statistic measured at the USGS gaging station at the Wax Lake Outlet (WLO) in Calumet, LA (USGS, station \#07381590) located approximately $21 \mathrm{~km}$ upstream of the delta apex (Figure 2). Low flow is defined by discharges lower than the 15 -year median daily statistic. Daily statistics for discharge are computed at this station hereafter referred to as WLO station for the period from September 2000 to September 2015. I use high flow and flood interchangeably throughout this text although these terms do not imply exceedance of bankfull discharge.

Peak discharge during a high flow event typically occurs between December and the following July. The average annual peak water discharge was $5,400 \mathrm{~m}^{3} / \mathrm{s}$ and the average annual discharge was $2,500 \mathrm{~m}^{3} / \mathrm{s}$ measured at the WLO station between 1985 and 2016 (USGS, station \#07381590). Annual sediment delivery is estimated to be 38.4 megatons, $18 \%$ being sand (Kim et al., 2011). The mean tidal range is $0.35 \mathrm{~m}$ measured at $10 \mathrm{~km}$ southeast of the WLD on the Atchafalaya Delta (Figure 2) and is assumed to represent conditions comparable to that on the WLD (NOAA, station \#8764227). The mean significant wave height is less than $0.5 \mathrm{~m}$ (Wright, 1977). Annual passage of winter cold fronts between October and April can affect the hydrologic regime of the WLD. Winter cold fronts cause winds to be stronger and the north and northwest wind frequency increases and generates waves that provide a priming mechanism that ultimately maximizes sediment resuspension (Walker \& Hammack, 2000). 


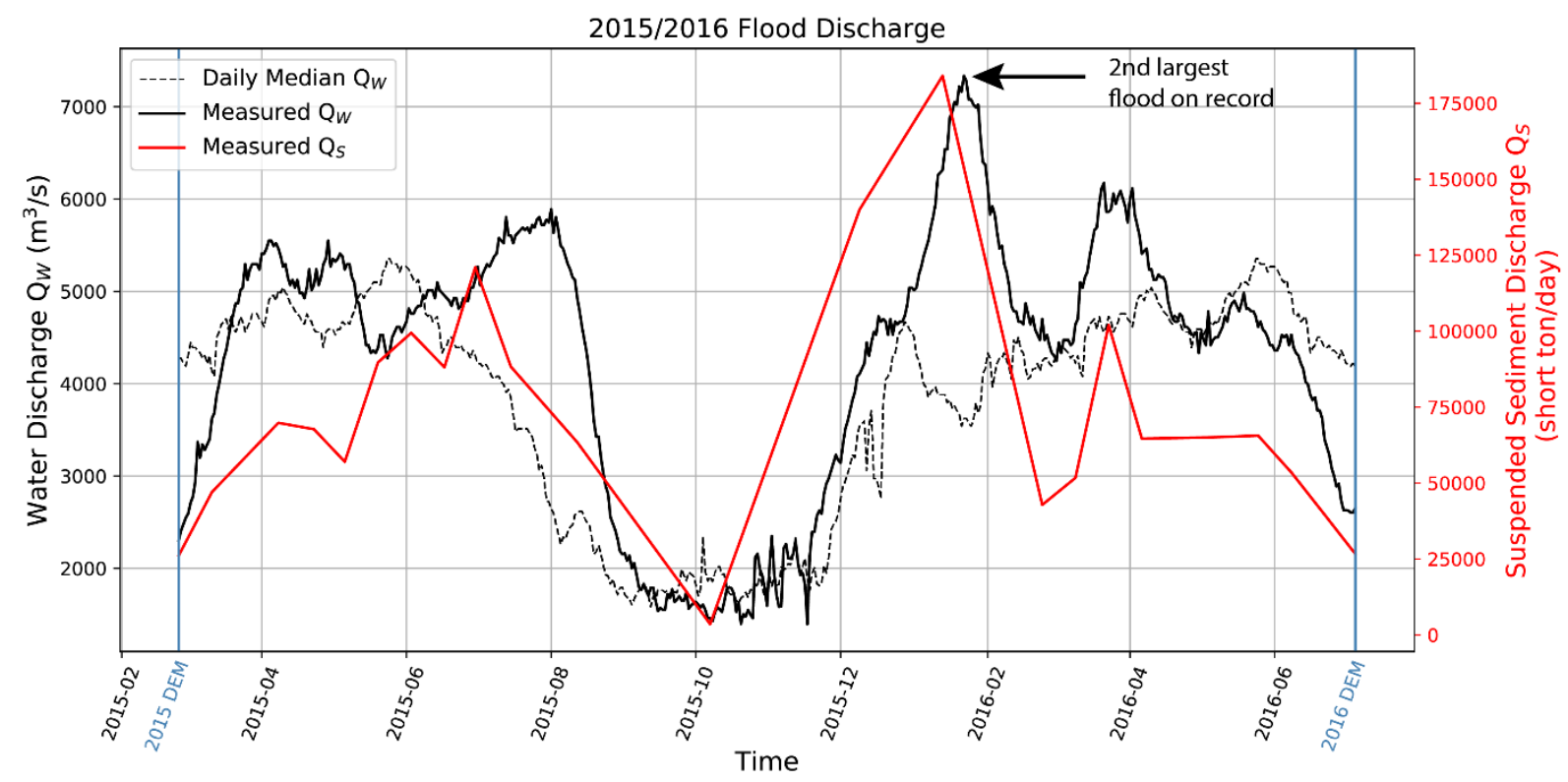

Figure 3. Water and Suspended Sediment Discharge measured for the 2015/16 flood. Discharge data are measured at the USGS gaging station on the WLO in Calumet, LA (USGS, station \#07381590) located approximately $21 \mathrm{~km}$ upstream of the delta apex. Measured water discharge (solid black line) is positively correlated with sediment discharge (solid red line) for a majority of the 496-day inter-survey period. Episodes of high flow are defined by exceedance of the 15-year daily median discharge (dashed black line). The daily median statistic at this station is computed for the period from September 2000 to September 2015.

Two high flow events were observed during this study's survey period between February $25^{\text {th }}$, 2015 and July $5^{\text {th }}, 2016$ which I refer to as the 2015-16 flood (Figure 2). Low flow events were captured at the start and end of the survey as well as during the survey between November and December 2015. During the 496-day survey period, flow conditions were in high flow $\sim 63 \%$ of the time. Average discharge during the survey period was $4,300 \mathrm{~m}^{3} / \mathrm{s}$. Peak discharge for the first high flow event occurred on August $1^{\text {st }}, 2015$ at 5,900 m³/s whereas the larger, second high flow event occurred on January 22 $2^{\text {nd }}, 2016$ at 7,300 $\mathrm{m}^{3} / \mathrm{s}$. The historic 2011 Mississippi flood resulted in a peak discharge of $9,100 \mathrm{~m}^{3} / \mathrm{s}$ and an approximate reoccurrence interval of 11 years compared to 8 years (not corrected for tidal effects) for the January 2016 high flow event calculated from 
data measured at the WLO between 1996 and 2016 (USGS, station \#07381590). The average suspended sediment discharge for the survey period was $6.53 \times 10^{4}$ metric tons/day.

\section{Methods}

\subsection{Bathymetric Surveys}

\subsubsection{Data Collection}

Available satellite imagery and or a DEM of the WLD was uploaded to a handheld GPS unit where survey routes were constructed. Survey routes were designed to gather a greater density of points in areas of steep slopes such as channel margins and a lower density of points elsewhere. Preexisting routes were adapted or additional routes were added in the field where slope changed unexpectedly. In some cases, routes had to be abandoned in depths too shallow for boat operation. Ideally, surveys were conducted during high tide to maximize navigable area however surveys were often time constrained.

Bathymetric data were collected with an HDS-7 Gen2 and HDS-7 Gen2 Touch depth sounder from Lowrance Electronics Inc. mounted on a $10 \mathrm{~m}$ pontoon boat and $5 \mathrm{~m}$ center console boat. The depth sounders have an integrated 12-channel GPS. The sonar head was equipped with a standard dual frequency of 50 and $200 \mathrm{kHz}$ transducer mounted at the stern of the boat. The data was collected under the default setting of $200 \mathrm{kHz}$ which has the highest sensitivity and best target discrimination in shallower water. The transducer sends out a beam of sound waves that disperses as it travels through the water column. The extent to which the sound beam spreads out is approximated by a cone. An echo is produced by the first reflection (shallowest point) encountered within the cone area by the sound beam. The return time of the speed of sound in water is calibrated for temperature but not salinity. The depth below the transducer is calculated from the return time 
and recorded every three milliseconds to an internal memory card along with latitude, longitude, and time since logging initiated. Boat speeds were generally less than that of the water or slower if air was caught in front of the transducer from air bubbles or if the transducer momentarily surfaced. The two surveys conducted in this study took five consecutive days each of surveying to complete.

\subsubsection{Data Cleaning}

The raw depth data was primarily cleaned in Matlab. Time of the sounding was converted to digital day. Degrees of latitude and longitude were converted into vectors of UTM coordinates and referenced to WGS84 horizontal datum. Depth was referenced to mean lower low water (MLLW) using water level data from the tide gage station on the Atchafalaya Delta mentioned above. The water level data for the survey period can be exported as tabular data in meters referenced to MLLW in as short as six minute intervals. The time of the water level measurements were also converted to digital day so that the water level could be linearly interpolated at the time of each sounding. Depth below the water surface to the transducer was recorded in the field and added to the referenced depth measurements. To deal with the enormous dataset generated by depth soundings acquired every 3 milliseconds, the depth measurements were linearly interpolated every $10 \mathrm{~m}$ along the planar distance traveled by the boat. A database file was created containing UTM coordinates and depth below MLLW that could be directly imported into ArcMap.

\subsection{DEM Generation}

Available satellite imagery and or a DEM of the WLD was imported into ArcMap in order to generally guide the process of manually contouring the bathymetry map from the depth measurements. The database file was exported as a shapefile so that the points can be visualized. A shapefile of 'polyline' type with an elevation attribute was created. The shapefile editor was 
used to build contours in the polyline shapefile by manually drawing contours with $20 \mathrm{~cm}$ spacing. Contours were reliably placed between points based on a data visualization technique that takes advantage of the 'define classes' option in point symbol properties. Areas with low point density were contoured based on an intuitive expectation of subaqueous surface behavior. The 'Topo to Raster' extension of 3D Analyst in ArcMap was then used to create a Digital Elevation Model. Each DEM was created with the same boundary clipping. The boundary clipping was based on the 2015 survey extent which only included the subaqueous portion of the delta front. I chose not to enforce drainage. The resulting DEMs from February 2015 and July 2016 each have an output cell size of $25 \mathrm{~m}$ (See Figure 4). The choices for cell size and contour interval are liberal given the instrument accuracy which I show to have the largest effect on horizontal and vertical measurement accuracy in Appendix A. As a result, I believe the measurement accuracy has a negligible effect on the resultant DEMs and DoD. 


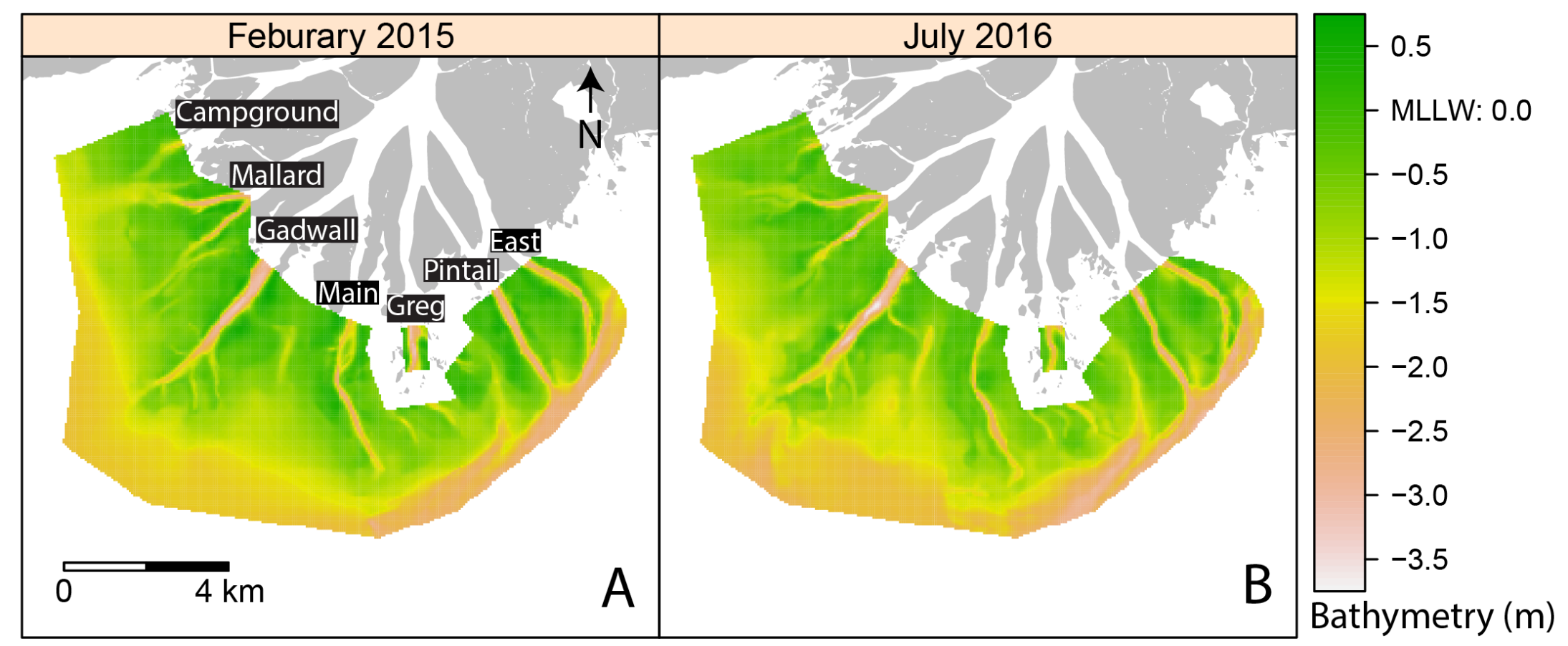

Figure 4. A) Bathymetry map interpolated in ArcMap from depth measurements collected with a depth sounder in February 2015 and B) July 2016. Elevation is referenced to MLLW using continuous water level data acquired from Amerada Pass tide gauge (National Oceanic and Atmospheric Administration [NOAA] station \#11354, $4.2 \mathrm{~km}$ east of map). I surveyed the subaqueous portions of 7 channels denoted in A: Campground, Mallard, Gadwall, Main, Greg, Pintail, East. 


\subsection{Volume of Suspended Sediment Delivered}

I estimated $V_{\text {Delivered }}$, the volume of suspended sediment delivered, for the 496 day survey period using data accessed online at waterdata.usgs.gov for station \#07381590 on the WLO in Calumet, LA. Relevant parameter codes retrieved for data processing in Matlab are P00061 (discharge, instantaneous, in cubic feet per second), P70331 (suspended sediment, sieve diameter, percent smaller than 0.0625 millimeters), P80154, (suspended sediment concentration, milligrams per liter), and P80155 (suspended sediment discharge, short tons per day). The water discharge record is continuous however suspended sediment discharge measurements are recorded irregularly and less frequently. Suspended sediment discharge was converted from short tons per day to metric tons per day and then to cubic meters per second using a porosity of $72 \%$ and an assumed sediment density $2650 \mathrm{~kg}$ per $\mathrm{m}^{3}$. I estimated the porosity of the deposits from the average of four bulk density measurements collected from the delta top between 2009 and 2015 (Bevington et al., 2017). The porosity of $72 \%$ is assumed to accurately reflect the deposits in the survey area. After the suspended sediment discharge was linearly interpolated on the first and last day of the survey period, I integrated over the survey period to get total $V_{\text {Delivered }}$ to the entire WLD which I found to be $4.58 \times 10^{7} \mathrm{~m}^{3}, 84 \%$ of which was composed of grains smaller than $0.0625 \mathrm{~mm}$ (USGS, station \#07381590). I also calculated total $V_{\text {Delivered }}$ from the suspended sediment concentration and water discharge in order to corroborate the first estimation. For this calculation I first had to linearly interpolate the suspended sediment concentration on the first and last day of the survey period. Multiplying water discharge in liters per second by the suspended sediment concentration yields the suspended sediment discharge in milligrams per second. I converted this to cubic meters per second using the same assumptions mentioned above and then integrated over the 496 day 
survey period to arrive at a secondary estimation of total $V_{\text {Delivered }}$ which was $4.59 \times 10^{7} \mathrm{~m}^{3}$. I will use the first estimation of total $V_{\text {Delivered }}$ in the analyses to follow.

\subsection{Nourishment Boundaries and Flow Partitioning}

Nourishment boundaries, the interface that divides two distinct nourishment areas, were primarily inferred from flow patterns for each distributary pass on the WLD. Flow patterns can be reliably identified using SAR (Synthetic Aperture Radar) imagery due to the presence of naturally occurring (biogenic) surface films that converge on the water surface under the influence of the dominant flow direction. These surface films appear darker in the SAR imagery as they have the effect of smoothing the water surface which results in a lower radar backscatter signal compared to the surrounding water (Espedal, Johannessen, \& Knulst, 1995). Therefore, the surface films map the areas on the WLD that generally receives water and sediment from a given distributary pass. I used SAR imagery acquired in 2015 to delineate nourishment boundaries in the survey area. The 2016 DEM was also used to delineate nourishment areas by the presence of interdistributary troughs which are expressed as linear, bay-ward trending bathymetric lows between nourishment areas (Shaw, Mohrig, David, \& Wagner, 2016). Nourishment areas are analogous to catchment areas in tributary systems however nourishment areas are not closed, meaning the bay-ward boundary is open to water and sediment exchange with the receiving basin (Edmonds et al., 2011). However, I closed the boundaries on the bay-ward side of all nourishment areas with the survey boundary (Figure 5) in order to perform the analyses below. Consequently, all nourishment area sizes are likely underestimates of their true size.

I seek to test if the distribution of flow between distributary channels scales with the distribution of net deposition within the channel's respective nourishment area. Distributary pass flow partitions were acquired from point discharge measurements collected in February 2012 during a 
period of high flow (M. R. Hiatt, 2013). I chose 7 locations from this dataset, one for each distributary pass, that represented the closest upstream location to the survey area. I refer to this subset of the discharge measurements as the Hiatt flow partitions. I take the total channelized discharge reaching the subaqueous portion of the survey area to be the sum of the Hiatt flow partitions, $Q_{S a q}$, whereas $Q_{\text {Apex }}$ will refer to the discharge measured at the apex during the time period the Hiatt flow partitions were acquired which was $4250 \mathrm{~m}^{3} / \mathrm{s}$.

\section{Results}

\subsection{DEM of Difference}

The 2015 DEM was subtracted from the 2016 DEM using the "Raster Calculator" tool in Arcmap. I used the resultant DoD to determine the volume of erosion $\left(V_{\text {Erosion }}\right)$ and volume of deposition $\left(V_{\text {Deposition }}\right)$ by multiplying the cell area, $A\left(625 \mathrm{~m}^{2}\right)$, by the sum of the cell values $(\Delta \hat{z})$ with either negative or positive bathymetric change (Equation 1a and 1b). I use the terms erosion and deposition here because I interpret sediment arrival and removal to be the primary controls on bathymetric change, although I discuss other secondary drivers in Discussion section 6.1.2.

$$
\begin{gathered}
V_{\text {Erosion }}=A * \sum(\Delta \hat{z}<0) \\
V_{\text {Deposition }}=A * \sum(\Delta \hat{z}>0)
\end{gathered}
$$

The net volume change, $V_{N e t}$, was determined by summing $V_{\text {Erosion }}$ and $V_{\text {Deposition }}$ :

$$
V_{\text {Net }}=V_{\text {Erosion }}+V_{\text {Deposition }}
$$

[Equation 1c] 


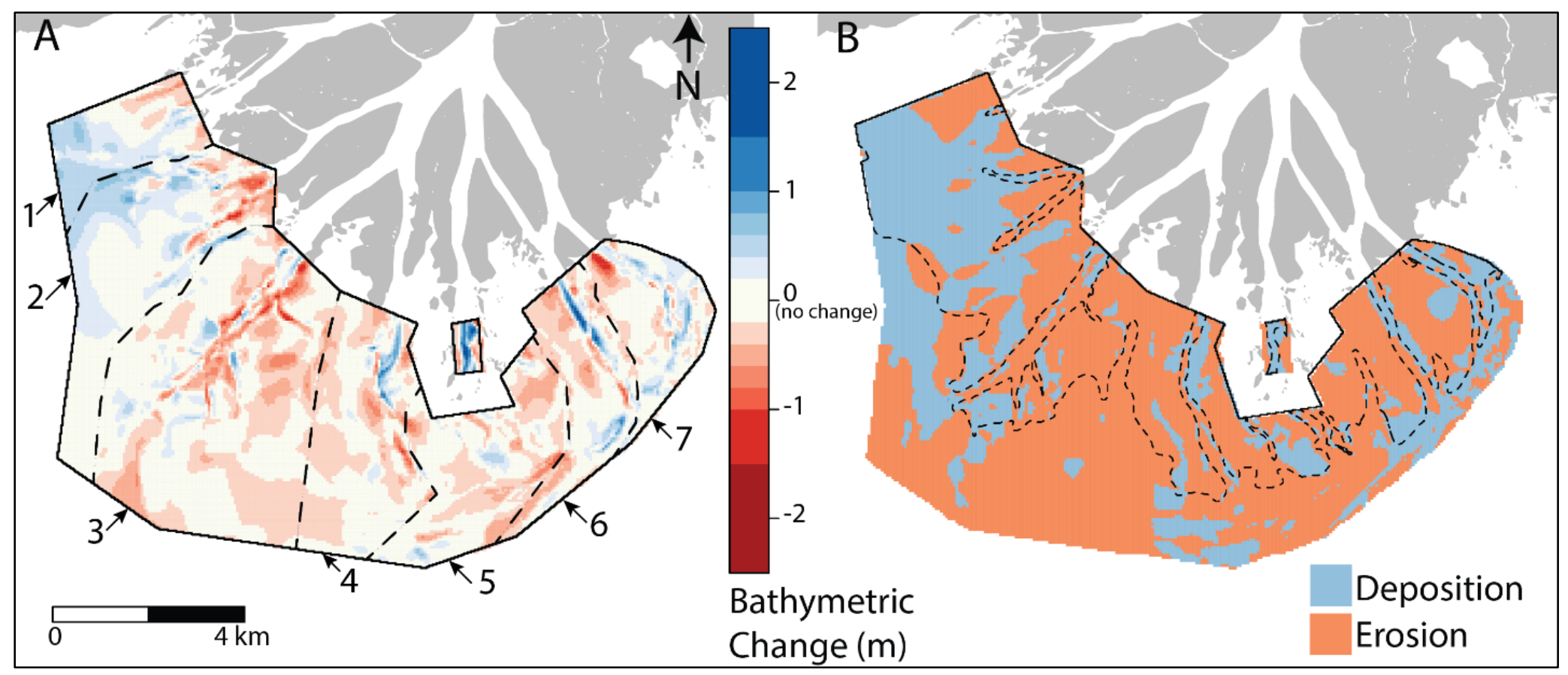

Figure 5. A) DEM of difference. Bathymetric change in meters calculated by differencing bathymetric maps from February 2015 (Fig 4A) and July 2016 (Figure 4B). Red indicates areas of erosion, blue indicates areas of deposition, and yellow indicates areas of no change. Dashed black lines delineate survey nourishment areas $N A_{\text {Survey }}$, which were estimated from flow patterns and bathymetry (Section 3.5). Nourishment areas are numerically acknowledged based on the distributary pass that supplies water and sediment to it ( 1 = Campground, $2=$ Mallard, $3=$ Gadwall, $4=$ Main, $5=$ Greg, $6=$ Pintail, $7=$ East $)$. B) Distribution of erosion and deposition. Cells where $\Delta \hat{z}<0$ are colored red and represent erosion whereas cells where $\Delta \hat{z}>0$ are colored blue and represent deposition. The $2016-1 \mathrm{~m}$ contour is delineated with a black dashed line. 
The DoD (Figure 5) showed $6.41 \times 10^{6} \mathrm{~m}^{3} \pm 3.70 \%$ of sediment were deposited and $1.19 \times 10^{7} \mathrm{~m}^{3} \pm 2.71 \%$ were eroded, yielding $5.46 \times 10^{6} \mathrm{~m}^{3} \pm 7.32 \%$ of net erosion in the survey area $\left(\sim 75.9 \mathrm{~km}^{2}\right)$. See Appendix C for uncertainty in volume estimates.

The space- and time-averaged erosion and deposition rate was $-0.32 \pm 0.011 \mathrm{~mm} /$ day and $-0.17 \pm$ $0.006 \mathrm{~mm} /$ day. Erosion occupied $65 \%$ of the total survey area while deposition occupied $35 \%$. DoD summary statistics are displayed in Table 1 below.

Table 1. Summary Statistics for DEM of Difference.

\begin{tabular}{|l|l|}
\hline Statistic & Value $(\mathbf{m})$ \\
\hline Maximum Erosion & 1.52 \\
\hline Maximum Deposition & 2.24 \\
\hline Mean per cell & -0.07 \\
\hline Mode per cell & -0.18 \\
\hline Median per cell & -0.11 \\
\hline Standard Deviation & 0.30 \\
\hline
\end{tabular}

\subsection{D Changes to Subaqueous Delta Bathymetry}

\subsubsection{Delta Front Area}

I can track changes to delta front area by mapping the movement of the $1 \mathrm{~m}$ contour below MLLW between the two DEMs. I find that the most eastern and western portion of the WLD is characterized by area gain while the central portion of the delta is characterized by area loss (Figure 6). I can calculate the increase in delta front area above this elevation inside the survey area by closing this contour with the survey boundary and at channel tips where necessary (Figure 6 inset map). I found that the area above the $-1 \mathrm{~m}$ contour decreased in size by $0.03 \mathrm{~km}^{2}$. This decrease in area would be more pronounced if it were not for the large swath of net deposition located bayward of the Campground and Mallard Pass channel tips. The central portion of the delta front retrograded an average of $145 \mathrm{~m}$. 


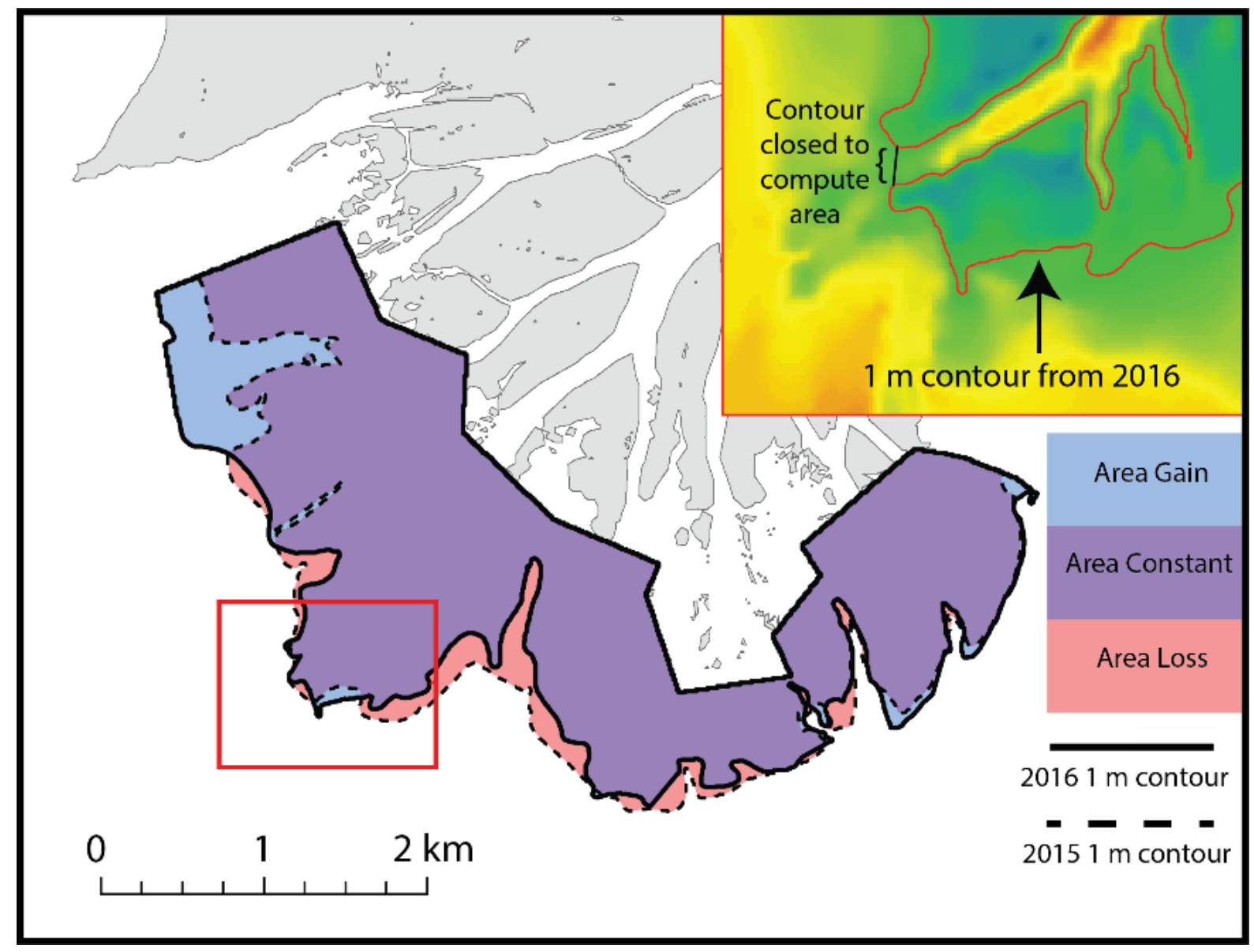

Figure 6. Changes to delta front area. The western portion of the WLD gained while the central portion lost area. Delta front area was computed by calculating the area inside the $-1 \mathrm{~m}$ contour from the 2015 DEM (red polygon, dashed outline) and 2016 DEM (blue polygon, solid outline). The $-1 \mathrm{~m}$ contour was closed in some places in order to calculate area (see inset map). 


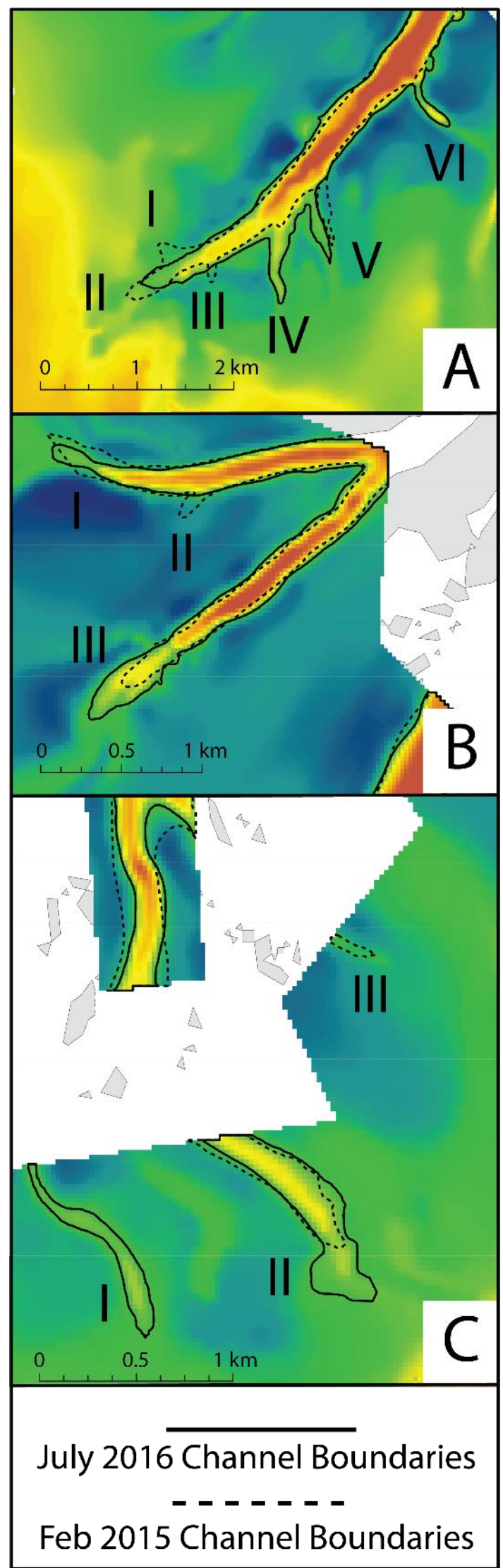

\subsubsection{Channel Planform}

Channel boundaries for 2015 and 2016 were delineated based on the $1 \mathrm{~m}$ contour below MLLW, again closing channel tips where necessary. The dominant channel configuration consisting of 7 primary channels remained unchanged during the survey period. Channel reorganization was focused in subordinate channels which I define as bifurcations with channel widths less than half of its parent channel. I observed three instances of subordinate channel abandonment (Mallard II, Gadwall I, III) and two instances of subordinate channel formation (Greg I, Gadwall VI) (Figure 7). $60 \%$ of channels experienced channel tip extension. Maximum channel tip extension occurred on a subordinate channel on Gadwall Pass at $790 \mathrm{~m}$ ( 2 channel widths).

\section{Figure 7. Changes to Channel Organization and} Planform. Channel boundaries were delineated based on the $1 \mathrm{~m}$ contour generated from the 2015 DEM (dashed line) and 2016 DEM (solid line). The 2016 DEM is displayed in the background for reference. A) Gadwall Pass. Channel I and III were abandoned and Channel VI formed while Channel V experienced the greatest lateral migration. Maximum channel tip retreat and extension also occurred on II and IV, respectively. B) Mallard Pass. Channel II was abandoned. C) Greg Pass. Channel I formed. Channel III may have been abandoned but it is not certain due to not enough data. 
Maximum channel tip retreat occurred on the main tip of Gadwall Pass at $192 \mathrm{~m} \mathrm{(} \mathrm{1/2} \mathrm{channel}$ width). Channel displacement was negligible for a majority of channels except on Gadwall V which translated west-southwest by $122 \mathrm{~m}(\sim 1 / 3$ channel width $)$ and is expressed as a southtrending linear scour (red) beside a south-trending linear channel fill (blue) in the DoD (Figure 5). Changes to channelized area were negligible for most channels.

\subsection{D Subaqueous Delta Evolution}

\subsubsection{Channel Aggradation and Incision}

The 2015 and 2016 channel boundaries were merged in order to take channel migration into account for volume change calculations. Five out of seven distributary passes were netaggradational. Mallard and Gadwall Passes were the only net-incisional passes. The largest decrease in elevation between the 2015 and 2016 survey occurred in the channel thalweg of Gadwall Pass and the largest increase in elevation occurred in the channel thalweg of Greg Pass (Table 1). $12 \%$ of total $V_{\text {Erosion }}$ and $20 \%$ of total $V_{\text {Deposition }}$ originated from within the channel boundaries which comprises $8 \%$ of the survey area. Finally, visual observation of the DoD reveals that most levees proximally located to the apex experienced deposition.

\subsubsection{Nourishment Areas}

The DoD was "clipped" using the polygon shapefiles of the nourishment area boundaries displayed in Figure 5A. Equations $1 \mathrm{a}, \mathrm{b}$, and $\mathrm{c}$, were then used to calculate $V_{\text {Erosion }}, V_{\text {Deposition }}$, and $V_{N e t}$ for individual nourishment areas. Most nourishment areas were net-erosional except Campground (strongly net-depositional) and Mallard (weakly net-depositional) (Figure 8). It is unknown if East was net-erosional or net-depositional given that the uncertainty in the volume is greater than the volumetric change East experienced (Table 2, Appendix C). Gadwall nourishment area was the

most net-erosional and Mallard was the most net-depositional (Figure 8). $V_{\text {Erosion }}$ in Gadwall 
nourishment area accounted for $40 \%$ of total $V_{\text {Erosion }}$ in the survey area while $V_{\text {Deposition }}$ in Campground nourishment area accounted for $20 \%$ of total $V_{\text {Deposition. }}$. Based on these results, it is not surprising that Gadwall and Campground nourishment areas had the smallest $V_{\text {Deposition }}$ and $V_{\text {Erosion }}$, respectively (Figure 8). The correlation between nourishment area size and $V_{\text {Erosion }}$ in a nourishment area is strong $(\mathrm{r}=0.93)$ whereas nourishment area size and $V_{\text {Deposition }}$ in a nourishment area are not correlated $(\mathrm{r}=0.04)$.

\subsection{Flow Partitioning and Volume of Suspended Sediment Delivered}

I can perform a flow partitioning analysis of the subaqueous portion of the delta by comparing $Q_{\text {Saq }}$, the sum of the Hiatt flow partitions, to $Q_{\text {Apex }}$, the discharge measured at the apex during the time period the Hiatt flow partitions were acquired. I find that $Q_{S a q}$ only accounts for approximately $40 \%$ of $Q_{\text {Apex }}$. If I take $Q_{\text {Saq }}$ to represent the total discharge reaching the survey area, I can verify that flow is non-uniformly distributed between the 7 distributary channels on the WLD. Gadwall Pass receives the greatest portion of flow at $\sim 21 \%$ of $Q_{S a q}$ while the smallest portion is allocated to Pintail Pass at $\sim 8 \%$ (Table 2). 
Table 2. Channelized discharge measurements for the subaqueous portion of the survey area and their sum, $Q_{\text {Saq }}$, compared to $Q_{\text {Apex }}$, the discharge measured at the apex during the time period the Hiatt flow partitions were acquired. $V_{\text {Delivered }}$ to each nourishment area was obtained by multiplying percentage of $Q_{\text {Apex }}$ by total $V_{\text {Delivered }}$ (total suspended sediment discharge for the 496 day inter-survey period which was $4.58 \times 10^{7} \mathrm{~m}^{3}$ ).

\begin{tabular}{|l|l|l|l|}
\hline \multicolumn{1}{|c|}{ Channel } & \multicolumn{1}{|c|}{$\begin{array}{c}\text { Discharge from } \\
\text { Hiatt et al. 2012 } \\
\left(\mathrm{m}^{3} / \mathbf{s}\right)\end{array}$} & $\begin{array}{c}\text { Percentage }(\%) \text { of } \\
Q_{\text {Apex }}\end{array}$ & $\begin{array}{c}V_{\text {Delivered }} \\
\left(\times 10^{6} \mathrm{~m}^{3}\right)\end{array}$ \\
\hline Gadwall & 360 & 21.0 & 3.83 \\
\hline Main & 276 & 16.1 & 2.94 \\
\hline Greg & 305 & 17.8 & 3.25 \\
\hline Pintail & 140 & 8.1 & 1.49 \\
\hline East & 239 & 13.9 & 2.56 \\
\hline Mallard & 200 & 11.6 & 2.13 \\
\hline Campground & 198 & 11.5 & 2.11 \\
\hline Subaq. Delta TOTAL & Sum $=\boldsymbol{Q}_{\text {Saq }}=\mathbf{1 7 1 8}$ & $\boldsymbol{Q}_{\text {Saq }} / \boldsymbol{Q}_{\text {Apex }}=\mathbf{4 0 . 0}$ & $\mathbf{1 8 . 3}$ \\
\hline
\end{tabular}

I estimated the volume of suspended sediment delivered $\left(V_{\text {Delivered }}\right)$ to each distributary pass during the survey period by multiplying the fraction of $Q_{\text {Apex }}$ each distributary channel receives in Table 2 by the total $V_{\text {Delivered }}$ for the 496 day inter-survey period which was $4.58 \times 10^{7} \mathrm{~m}^{3}$ (Section 3.4). Total $V_{\text {Delivered }}$ to the subaqueous portion of the delta was $18.3 \times 10^{6} \mathrm{~m}^{3}$. $V_{\text {Delivered }}$ to a nourishment area exceeded $V_{\text {Net }}$ measured in that nourishment area in all cases. Since Gadwall receives the greatest proportion of flow, it received the greatest proportion of the total $V_{\text {Delivered }}$ (Table 2). I initially hypothesized that the delta front would be net-depositional and $V_{N e t}$ would be greatest in Gadwall nourishment area. In fact, Gadwall nourishment area was strongly net-erosional, as was the case for a majority of nourishment areas (Figure 8). Clearly, net deposition in a nourishment area cannot be predicted from discharge alone. For the two nourishment areas that were net-depositional, Campground and Mallard, I can compute the trapping efficiency as the fraction of $V_{N e t}$ in the nourishment area and $V_{\text {Delivered }}$ to that nourishment area. Multiplying by 100 yields a trapping efficiency of $46.7 \%$ and $42.6 \%$ for 
Campground and Mallard Pass. Note that these trapping efficiencies are likely biased due to my inability to survey the entire nourishment area.

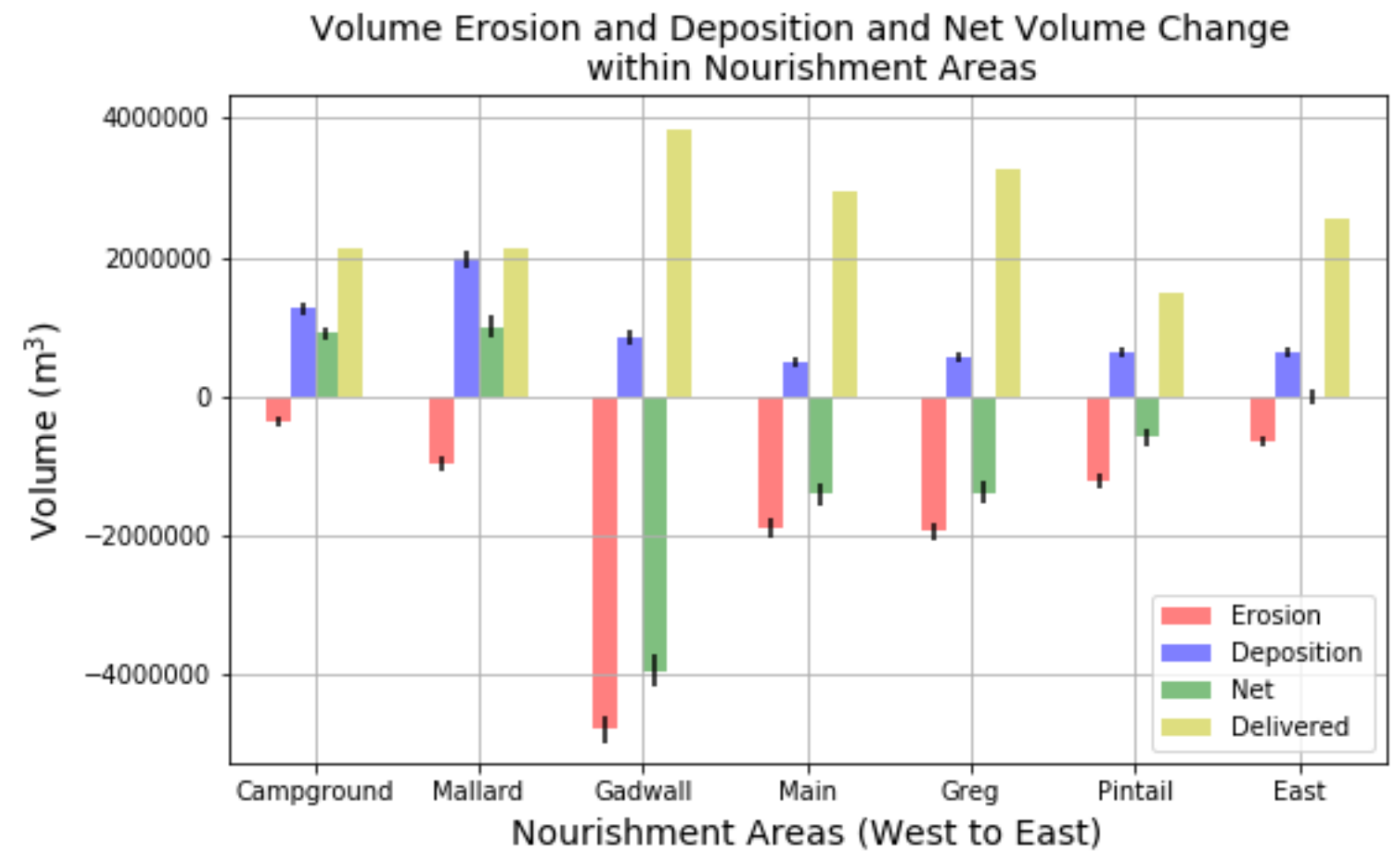

Figure 8. $V_{\text {Delivered }}$ (yellow) to each nourishment area and $V_{\text {Erosion }}\left(\right.$ red), $V_{\text {Deposition }}($ blue), and $V_{N e t}$ (green) measured in each nourishment area.

\section{Discussion}

\subsection{Patterns of Erosion and Deposition}

I characterized the two- and three-dimensional evolution of the delta front by visually and quantitatively assessing the DoD. A visual inspection of the DoD shows that a majority of the survey area was dominated by erosion (65\%) whereas deposition was more spatially localized (Figure 5). Summing the change that occurred at each cell revealed that the delta front was $2 \mathrm{x}$ more erosional than depositional. This result is surprising given that the WLD has experienced 
rapid subaerial growth over the past 40 years. It is also surprising that a major flood during the survey period did not result in net-deposition on the delta front considering floods are typically correlated with subaerial delta growth (Bevington et al., 2017; Carle et al., 2013; Roberts et al., 1980; Rosen \& Xu, 2013). In this section, I attempt to explain the presence of a net-erosional delta front on an actively growing delta by first identifying the spatial patterns of erosion and deposition and then attempting to infer the mechanisms that most likely produced these patterns. Isolating the factors that are the most and least influential to changing subaqueous delta bathymetry in this study is an important step to linking the subaerial and subaqueous delta growth in future studies.

\subsubsection{Erosion}

There were some localized areas of erosion such as the interdistributary bays, however, in general, erosion was much more spatially distributed compared to the depositional patterns I observed. The distribution of elevation change observed from the DoD raster cells has a non-zero mode of -0.18 $\mathrm{m}$ and a mean of $-0.07 \mathrm{~m}$ (Table 1) which implies that there exists an erosional process that affects a majority of the survey area. There is a strong positive correlation between nourishment area size and volume of erosion within a nourishment area which also points towards a process that affects the whole delta (Section 4.3.2). While there are many processes that interact to generate the erosional patterns here, I discuss those which likely have the greatest importance in causing $2 / 3$ of the survey area to experience erosion those being tides and wave resuspension from wind. I also discuss the effect of subsidence in the survey area. Even though it is not an erosive mechanism, it would cause an observed lowering of the bed, giving the appearance of erosion.

Although tides conceivably affect sediment transport everywhere on the delta front, even in a micro-tidal environment, they have been shown to focus erosion on distributary channel tips during low flow events (Hanegan \& Georgiou, 2015). Spatial acceleration of the flow near the channel 
tips creates bed shear stress sufficient enough to entrain fine sand in suspension resulting in erosion of channel tips. The result that $60 \%$ of channel tips extended likely occurred during low flow which accounted for $37 \%$ of the total survey period time. Channel tip extension was also observed following a low flow event in a similar bathymetric change study (Shaw \& Mohrig, 2014). Though tides during low flow have a considerable impact on erosion of channel tips, they do not explain widespread erosion on the delta front.

Wave resuspension from wind is capable of causing widespread erosion. Wind exerts a stronger control on water levels in Atchafalaya Bay compared to river discharge during low flow according to (Walker \& Hammack, 2000). Winter cold fronts with northwest oriented winds during low flow can cause a decrease in water levels which acts to maximize sediment resuspension and transport in the bay. They claim that the northwest winds then export the re-suspended sediment out of bays by flushing large volumes of water onto the inner-shelf. Provided that winter cold fronts can occur 20-30 times a year (Walker \& Hammack, 2000), it is likely that a storm event or multiple storm events with such northwest-oriented winds could have re-suspended sediment and transported it out of the system resulting in a distributed erosional signature. Interestingly, winter cold front removal of sediment was also observed on the subaerial portion of the delta (Bevington et al., 2017). This suggests that winter cold fronts act to remove mud and fine sediments off the delta top as well as the subaqueous portion of the delta, providing a significant sediment source for Atchafalaya Bay.

It is interesting that the only nourishment areas to experience net deposition and essentially no net volume change are located on the west and east flanks of the delta, respectively (Figure 8). Though these areas are slightly shallower than the rest of the survey area and wind-wave suspension would be maximized here, it is possible that their location shelters them from the major discharge paths 
that would otherwise export large volumes of water and sediment from these nourishment areas during passage of a winter cold front. I discuss localized deposition on the flanks of the delta more extensively in the following section.

It is impossible to predict how much erosion I can attribute to winter cold fronts. Therefore, it is worth exploring other causes for widespread, distributed erosion, especially when twice as much volume was removed than added. A non-erosive mechanism that could also account for a large widespread decrease in volume is subsidence. I determined total subsidence during the survey period using elevation change and accretion measurements acquired from ten CRMS sites (Coastwide Reference Monitoring System) located within $15 \mathrm{~km}$ of the WLD. Elevation is measured every 6 months from a rod surface-elevation-marker horizon and accretion is measured as the thickness of deposited material above a feldspar marker horizon (Folse et al., 2014). A linear regression was used to estimate the total amount of elevation change and total accretion that occurred between February 25th, 2015 and July 5th, 2016. Subsidence is then calculated by subtracting the total elevation change from total accretion over the survey time period. Averaging the 10 sites yielded a total subsidence of $1.64 \mathrm{~cm}(1.21 \mathrm{~cm} / \mathrm{yr})$. Minimum subsidence was found to be $0.55 \mathrm{~cm}(0.40 \mathrm{~cm} / \mathrm{yr})$. The closest CRMS site to the survey area also subsided the most during the survey time period. Located on an island of the WLD, this site subsided $4.28 \mathrm{~cm}(3.16$ $\mathrm{cm} / \mathrm{yr}$ ). I can use this value as upper bound for the amount of subsidence that occurred everywhere in the survey area and compare it to the average elevation decrease per cell in order to determine how much of the bed lowering was caused by subsidence. Dividing total $V_{\text {Erosion }}$ by the total survey area results in an average elevation decrease of $15.6 \mathrm{~cm}$ per $25 \mathrm{~m}$ x $25 \mathrm{~m}$ cell. Subtracting $4.28 \mathrm{~cm}$ from the average elevation decrease per cell reveals that there is still a considerable elevation decrease and volume loss between surveys that was not caused by subsidence. 
There are various ways by which subsidence occurred in the survey area however subsidence due to shallow compaction and or fault slip are more likely the larger contributors. Shallow compaction of sediments can account for at least $60 \%$ of the total subsidence in the survey area (Jankowski, Törnqvist, \& Fernandes, 2017). Subsidence due to shallow compaction may vary considerably spatially, thus its effect in the survey area may not be uniform. This could explain the wide range in total subsidence measured for the CRMS sites mentioned above. Subsidence could also be largely influenced by fault slip given that numerous faults have been mapped in southern Louisiana, most of which are associated with salt tectonics. The Lake Hatch Fault trends E-W and is presumed to cross the WLD (Gagliano, 2003). Subsidence of the Lake Hatch fault was determined to be $1.95 \mathrm{~cm} / \mathrm{yr}$ for the period 1962-1978 at Houma, LA, located $\sim 70 \mathrm{~km}$ west of the WLD (Gagliano, 2003). Given its temporal and spatial separation, the slip rate of the Lake Hatch fault is likely not representative of the potentially active portion of the fault in the survey area. However, the mere presence of the Lake Hatch Fault does highlight the need to account for bed-lowering not caused by erosive processes.

\subsubsection{Deposition}

Deposition was more spatially localized compared to erosion. Deposition was confined to three main areas: channel beds, upstream reaches of channel levees, and the interdistributary bay between Campground and Mallard Pass. A majority of channels (5/7) experienced channel bed aggradation. Interestingly, Gadwall and Mallard Passes, the only channels that experienced channel incision, were also the only channels to experience subordinate channel abandonment (Figure 7). These results suggest that the delta is increasing in asymmetry over yearly timescales. As the net-aggradational channels shallow, more flow and sediment is diverted to one or more dominant channels with larger cross-sectional areas, likely Gadwall and or Mallard Passes. These 
results are consistent with models of distributary network growth where a majority of flow is allocated to $20 \%$ of channels (Edmonds et al., 2011).

Deposition was also localized on the most upstream portions of levees within the survey area. These areas of deposition are also coincident with the distal portions of island levees. Deposition on the distal portions of island levees likely corresponds with deposition in the proximal, subaerial portions of the islands, which is consistent with subaerial delta accumulation. Localized deposition on the upstream portions of levees conforms with the deltaic land building model presented by (Olliver \& Edmonds, 2017) in which land growth is achieved by subaqueous levee deposition which then allows for establishment of an intertidal platform and eventually a subaerial platform. Deposition on the subaqueous channel and island levee transitional zone was facilitated by the substantial flow exchange that exists between the distributary channels and islands (M. Hiatt \& Passalacqua, 2015). Sediment accumulates faster within this transitional zone compared to other locations within the survey area because it is the location that is most frequently, if not the only, subaerially exposed during low tide. Therefore, it is periodically sheltered from the erosive capabilities produced from wind from cold fronts or tides.

The third area where deposition was localized was the interdistributary bay between Campground and Mallard Pass. Deposition was likely localized here because these areas were sheltered from the erosive event(s) that caused widespread erosion in the survey area. As a result, it was more difficult to export sediment out of Campground and Mallard Pass nourishment areas. Still, the low trapping efficiencies estimated for Campground and Mallard Pass (Section 4.4) suggests that a majority of the sediment that arrived to these nourishment areas was exported out. 


\subsection{Effect of a Flood on Changing Subaqueous Delta Bathymetry}

We hypothesized that increased discharge and sediment input from upstream during the 2016 flood (Figure 3) would result in subaqueous delta growth however this was not the case. Despite the duration and magnitude of the flood event captured in this study, the average elevation of the subaqueous portion of the delta decreased (Table 1) and did not show any significant progradation (Figure 6). I argue that subaqueous delta growth is not strongly influenced by the flood cycle unlike subaerial delta growth which has been shown to follow timing of major floods (Bevington et al., 2017; Carle et al., 2013; Roberts et al., 1980; Rosen \& Xu, 2013).

An increase in channel network asymmetry on the scale of the distributary pass has been shown on Gadwall pass which both aggraded and increased its asymmetry following a flood (Shaw \& Mohrig, 2014). Though Gadwall Pass did not aggrade during this study, 5 out of 7 of the passes

did aggrade following the $2^{\text {nd }}$ largest flood in the WLD's recorded history. Floods therefore likely act to increase subaqueous delta asymmetry. Though I cannot directly confirm this, previous research suggests that a variety of perturbations from changes in channel bed morphology to changes in the flow regime, such as a flood, can ultimately drive bifurcations to become asymmetric (Edmonds \& Slingerland, 2008). In their study of deltaic bifurcations, (Edmonds \& Slingerland, 2008) showed that asymmetrical bifurcations are the most stable compared to symmetrical bifurcations which have roughly equal bifurcate channel widths, depths, and discharges. The Hiatt flow partitions verified that flow is indeed asymmetrically distributed between 7 distributary passes on the WLD, resulting in a non-uniform distribution of discharge (Table 2). The DoD provides direct evidence that the delta evolves toward a more asymmetric configuration. The observed increase in channel network asymmetry may be a direct 
morphological response to a large perturbation in the flow regime which certainly describes the flow conditions during the 2016 flood.

\subsection{Model for Subaqueous Delta Growth from Discharge to a Nourishment Area}

Given that flow is unevenly distributed between distributary channels (Table 2), I hypothesized that the volume of net deposition within a channel's nourishment area would also be unevenly distributed and scale with its discharge. My data did not support this hypothesis. For example, Gadwall Pass received the greatest proportion of flow and sediment and yet experienced neterosion; Mallard and Campground Pass received considerably less flow and sediment and yet were net-depositional (Table 2, Figure 8). The model for subaqueous delta growth from discharge to a nourishment area did not apply for a number of reasons. Firstly, the model does not account for sediment export out of a nourishment area and most nourishment areas were net erosional (Figure 8). The nourishment areas are also likely under-surveyed, thus the actual $V_{N e t}$ varies from the $V_{N e t}$ I measured in each nourishment area. I are confident in the relative proportions of $V_{\text {Delivered }}$ to each nourishment area however I acknowledge their magnitudes could be considerably different from the true $V_{\text {Delivered }}$ to each nourishment area.

\subsection{Decadal Growth of the Wax Lake Delta}

We found that the subaqueous portion of the WLD did not prograde significantly during the study except on the western portion of the delta where deposition was localized (Figure 6). The central portion of the delta retrograded an average of $145 \mathrm{~m}$ resulting in a negligible decrease in subaqueous platform area. The net loss in volume and decrease in area could suggest that the WLD is no longer prograding. However, this seems unlikely given that mapping of streaklines have revealed a gradual growth of the subaqueous delta (Shaw et al., 2018). Previous studies that estimate deltaic growth from remotely sensed data do not have the ability to explain the variability 
in the growth rates which can be negative over quasi-annual timescales (Allen et al., 2012; Shaw et al., 2018, Olliver \& Edmonds, 2018). The results presented here seem to indicate that the WLD can undergo minor decreases in delta area which could explain some of the variability in growth rates in the aforementioned studies.

The delta front did not efficiently trap sediment given its net erosional nature. If I only consider total $V_{\text {Deposition }}$, no more than $14 \%$ of the total $V_{\text {Delivered }}$ to the entire WLD was retained in the survey area (assuming that all deposition originated from sediment arriving from upstream). This study cannot resolve how much of the total $V_{\text {Delivered }}$ was trapped on the delta top nor how the growth of subaerial and subaqueous portion of the WLD is related. However, previous work found that the subaerial and subaqueous growth rates are remarkably similar averaged over decadal intervals but not so much over yearly intervals (Shaw et al, 2018). Clearly, simultaneous measurements of the marsh platform and delta front are needed; future studies that investigate the evolution of both regimes would be extremely valuable.

\section{Conclusions}

I was able to analyze the spatial distribution and magnitude of volume of erosion and deposition on the subaqueous portion of the WLD in coastal Louisiana by measuring change that occurred over $\sim 1$ year time period. This was accomplished by differencing two DEMs produced from data collected in February 2015 and July 2016. I report the presence of a net-erosional delta front of an actively prograding delta during the survey period. I identified distinct erosional and depositional patterns and attempted to infer the mechanisms that produced them. The patterns of erosion and deposition suggest that the two- and three-dimensional evolution of the delta front was primarily influenced by a wide spread erosional process, most likely wave resuspension from wind, with some apparent volume loss due to subsidence and tidal export during low flow. This wide 
spread erosional process had less of an influence in the western portion of the delta because it is relatively sheltered, resulting in localized deposition there.

We predicted that the subaqueous portion of the delta would be net-depositional and prograde during this study since the subaerial portions of deltas typically grow following major floods (Bevington et al., 2017; Carle et al., 2013; Roberts et al., 1980; Rosen \& Xu, 2013). Surprisingly, I found it was $2 \mathrm{x}$ more erosional than depositional. I conclude that subaqueous delta growth is less influenced by the flood cycle than the subaerial part of the delta, where deposition following a flood is well documented. A flood's main contribution to changing subaqueous delta bathymetry is to promote channel network asymmetry. Most of the suspended sediment load delivered by floods is likely trapped by deltaic islands thus promoting subaerial delta growth. The limited sediment supply to the subaqueous portion of the delta is then dominated by erosion due to winter cold fronts and tides or bed lowering due to subsidence. Localized deposition in the subaqueous channel and island levee transitional zone within the survey area supports previous research that showed delta progradation proceeds through a ecogeomorphic land building succession (Olliver \& Edmonds, 2017). It is unknown how the subaerial delta changed during the survey period but such information would make for an interesting comparison with the changes I measured on the delta front. Future studies should focus on the studying both regimes simultaneously.

The distribution of deposition within a nourishment area did not scale with discharge from the distributary pass that nourishes it, therefore deposition cannot be predicted from discharge alone. I conclude that models of subaqueous deltaic growth need to account for sediment export beyond the delta front.

Although a majority of channels extended during the survey period, I did not observe an increase in subaqueous delta area. The decrease in subaqueous delta area was negligible though it does 
highlight that the delta front can be retrogradational over short timescales. The difference between the observed change measured in this study compared to the decadal change for an actively prograding delta explains some of the variability in previously measured growth rates of the subaerial and subaqueous delta platform. The metrics I use to quantify deltaic growth may yield significantly different results compared to the same metric measured over decadal timescales; future work should consider the delta front to be a constantly changing environment on small temporal and spatial scales. Subaqueous delta growth forecasts subaerial delta growth since it forms the platform upon which islands grow (Cahoon, White, \& Lynch, 2011) thus accurately predicting subaqueous delta growth is highly valuable to planned or already implemented sediment diversions. I urge further exploration of this hidden portion of the delta in order to better understand and predict the short- and long-term evolution of the WLD as well as the evolution of all deltas, both modern and ancient.

\section{Appendices}

\subsection{Error Analysis}

In this section I compute the bias of the DoD inherently introduced from the contouring method and interpolation methods used to create the 2015 and 2016 DEMs. Manual contouring was preferred over automated contouring techniques available in ArcMap due to the density of survey transects. At large, stream-wise distances between channel transects, most algorithms used to contour point data do not connect channel thalwegs and instead interpolate a topographic high between the thalwegs. This "bubbling effect" in the resultant DEM could potentially be avoided with more closely spaced transects, however this is time-consuming and not cost-effective for repeat bathymetric surveys. The manual contouring method has the advantage of completely eliminating these interpolation errors, however biases are inherently introduced. 
To determine if the DoD exhibits a bias, I assume that the bathymetric change at any point on the delta is parameterized by $\Delta z$ which has a probability distribution for observed data, $\Delta z_{o b s}$, and an estimator $\Delta \hat{z}$, the DoD cell values, based on the observed data such that

$$
P_{\Delta z}\left(\Delta z_{o b s}\right)=P\left(\Delta z_{o b s} \mid \Delta z\right)
$$

[Equation 1]

In Eq. 1, $\Delta z_{o b s}$ is the difference between the depth value at a cleaned data point from the 2016 survey that is located within $3 \mathrm{~m}$ radially from the coordinates of a cleaned data point from the 2015 survey, i.e.,

$$
\Delta z_{o b s}=\left(z_{2016}\right)_{x_{b}, y_{b}}-\left(z_{2015}\right)_{x_{a}, y_{a}}
$$

where $x_{b}=r \cos (\theta)$ and $y_{b}=r \sin (\theta) ; \mathrm{r}$ is a distance between 0 and $3 \mathrm{~m}$ from the point $\left(x_{a}, y_{a}\right)$ and $\theta$ is an angle between 0 and $360^{\circ}$. If I then take $\Delta \hat{z}$ to be the difference values attained by differencing the 2016 and 2015 DEM depth values at the midpoint of $\left(x_{a}, y_{a}\right)$ and $\left(x_{b}, y_{b}\right)$, I can compute the bias of $\Delta \hat{z}$ relative to $\Delta z$ with Eq. 3:

$$
\operatorname{Bias}_{\Delta z}[\Delta \hat{z}]=E_{\Delta z_{o b s} \mid \Delta z}[\Delta \hat{z}]-\Delta z=E_{\Delta z_{o b s} \mid \Delta z}[\Delta \hat{z}-\Delta z]
$$

[Equation 3]

Where $E_{\Delta z_{o b s} \mid \Delta z}$ denotes the expected value over the distribution $P\left(\Delta z_{o b s} \mid \Delta z\right)$. An estimator is said to be unbiased if $\operatorname{Bias}_{\Delta z}[\Delta \hat{z}]=0$ for all values of parameter $\Delta z$. For a dataset of 927 observations, I find that $\operatorname{Bias}_{\Delta z}[\Delta \hat{z}]=0.0045$, therefore the change in elevation estimated by the DoD is largely unbiased. 


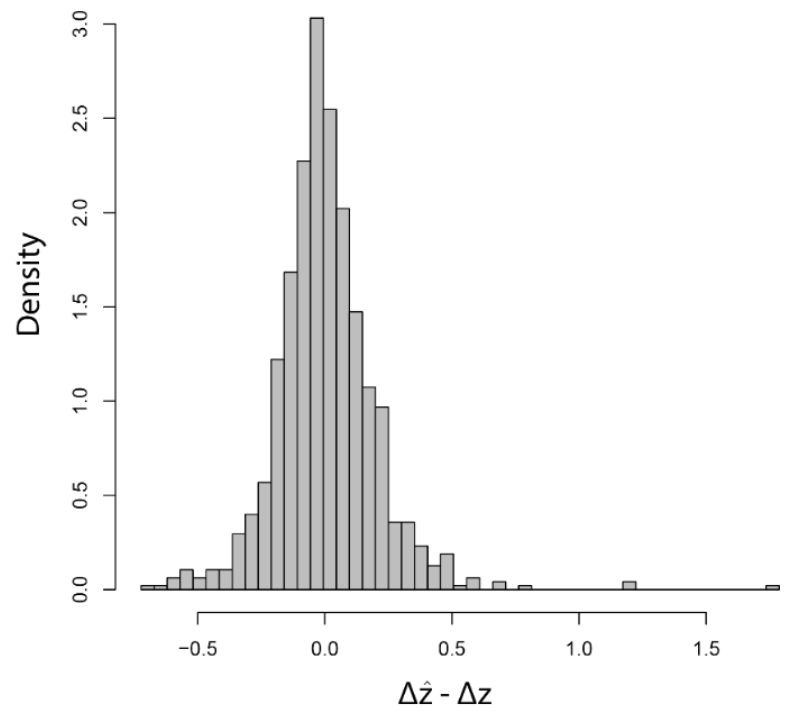

Figure 9. Bias in the change in elevation estimated by the DoD $\left(\operatorname{Bias}_{\Delta z}[\Delta \hat{\mathbf{z}}]\right)$. The bias of the DoD was computed to be -0.0045 therefore calculations derived from the DoD are not influenced by any unintentional differences in DEM generation methods.

\subsection{Measurement Accuracy}

Bathymetric surveying involves two primary independent measurements which are the horizontal position, (x-y location) and the vertical position (underwater bottom elevation). The horizontal position accuracy is dependent on the instrument accuracy of the GPS and the cone area of the depth sounder. The integrated GPS measurements are WAAS corrected (Wide Area Augmentation System) which generates measurement accuracy of $+/-4$ m upper $95 \%$ confidence limit (WAAS Performance Standard, 2008). The cone area is dependent on the survey depth and the depth sounder's beam angle; cone area increases with increasing depth and beam angle. For shallow depths $(<10 \mathrm{~m})$, the component of horizontal accuracy affected by the Lowrance cone area is higher $(+/-1 \mathrm{~m})$ than the WAAS corrected measurement accuracy (Heyman, Ecochard, \& Biasi, 2007) Since the survey area does not encompass depths $>10 \mathrm{~m}$, I used the GPS instrument accuracy to choose a large cell size of $25 \mathrm{~m}$ cell size for the DEMs. The vertical accuracy of the depth soundings is dependent on the instrument accuracy of the depth sounder and the speed of 
sound in water. Standard $200 \mathrm{kHz}$ depth sounders are accurate to within $+/-3 \mathrm{~cm}$ (Heyman et al., 2007). The depth soundings are corrected for temperature changes, but not salinity or depth. Salinity is assumed to be constant during the week of survey acquisition since the survey area is located sufficiently landward of the salinity front which has a range of $25 \mathrm{psu}$ in the mixing zone (Cobb et al., 2008). Even an unlikely 25 psu increase in salinity in the survey area would translate to a depth sounding $<2 \%$ deeper. Similarly, changes in the speed of sound due to depth will have a negligible effect on the depth sounding given that the speed increases linearly by $\sim 0.02 \mathrm{~m} / \mathrm{s}$ per meter increase in depth and the range in depth in the survey area is $3.5 \mathrm{~m}$ below MLLW. As a result, I chose a contour interval of $20 \mathrm{~cm}$ which is larger than the depth sounder instrument accuracy mentioned above.

\subsection{Uncertainty in Volume}

Uncertainty estimates for volumetric change calculations provides bounds for the reliability of the magnitude of sediment transport estimates and identified erosion and deposition areas on the WLD. The volume calculations are dependent on many random and systematic errors. Random errors, such as the sonar device's measurement accuracy, are shown to be small in Appendix B and are therefore ignored here. Systematic errors are identifiable though difficult to model. Systematic errors, such as the interpolation of the tide value used to reference the depth measurements to MLLW, is also assumed to have a negligible error. In order to determine the uncertainty in the volume, $\delta V o l$, I only consider the error associated with the contouring method and interpolation methods used to create the 2015 and 2016 DEMs. I first model the uncertainty using the error of the bathymetric change at an individual cell in the DoD, $\delta_{\Delta \hat{z}}$, as follows:

$$
\delta_{\Delta \hat{z}}=\sqrt{\frac{\sum\left(\Delta \hat{z}-\Delta z_{o b s}\right)^{2}}{n}}= \pm 0.20 \mathrm{~m}
$$


Where $\Delta z_{o b s}$ is the difference between a cleaned depth measurement from the 2016 survey and another cleaned depth measurement from the 2015 survey that is located within a 3 m radius of the 2016 measurement, $\Delta \hat{z}$ are the DoD cell values at the $\mathrm{x}-\mathrm{y}$ location of $\Delta z_{o b s}$ and $\mathrm{n}$ is the number of measurements from the 2015 survey that is located $<3 \mathrm{~m}$ from a measurement from the 2016 survey. Since the $\operatorname{Bias}_{\Delta z}[\Delta \hat{z}] \approx 0$ (Appendix A), I can assume a constant variance, $\delta_{\Delta \hat{z}}{ }^{2}$, and $\delta V o l$ can then be computed by multiplying by the number of cells, npix, and the cell area following Equation 5:

$$
\delta \text { Vol }=\text { Cell Area } * \delta_{\Delta \hat{z}} * \sqrt{n p i x}
$$

[Equation 5]

This method also assumes that the error of the bathymetric change is independent of any other cell. To test this second assumption, I computed the semivariogram of $\Delta \hat{z}-\Delta z_{o b s}$ as a function of $\mathrm{x}$ and $\mathrm{y}$. Using an exponential fit to the semivariogram, I found that $r=153.0 \mathrm{~m}$ and $p=0.037 \mathrm{~m}^{2}$ where $r$ is the distance at which observations are no longer dependent and $p$ is value that the semivariogram fit attains at $r$ (Figure 12). I then recalculated the uncertainty in volume to account for spatial autocorrelation using the information provided by the semiovariogram.

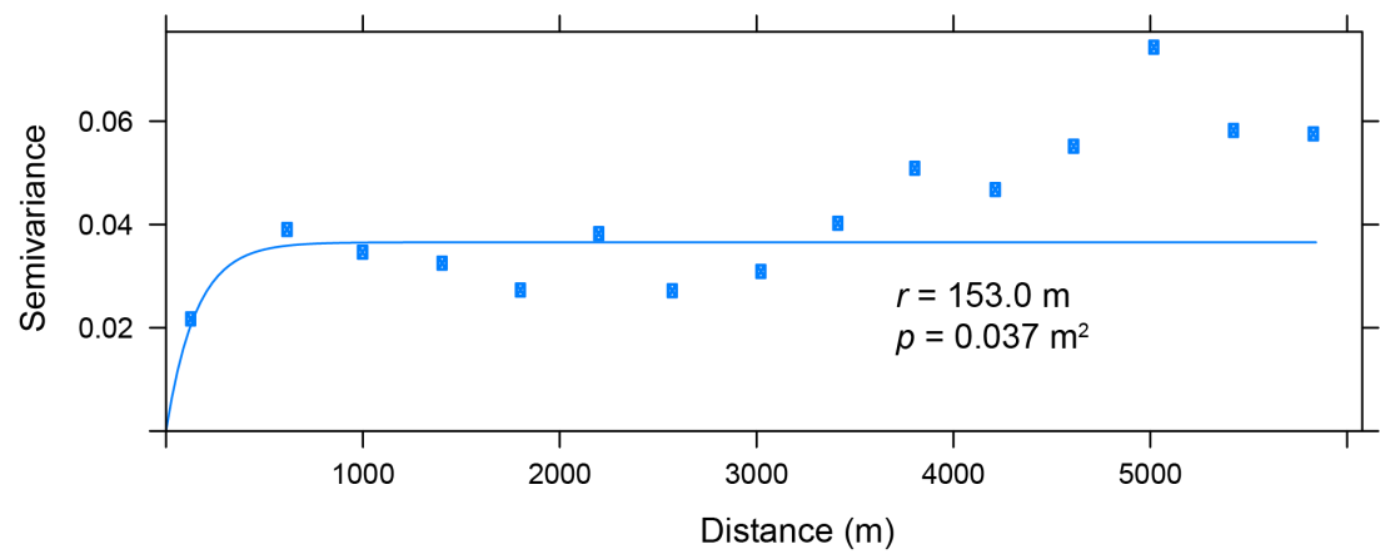

Figure 10. The semivariogram values for the averages of evaluated pairs of $\Delta \hat{z}-\Delta z_{o b s}$ (blue) and the estimated semivariogram fit (blue line). For any given cell in the DoD, it is spatially autocorrelated with surrounding cells within the range, $r$, of 153.0. The semivariance attained at $\mathrm{r}$ is $p=0.037 \mathrm{~m}^{2}$. 
Starting with a cell size of $25 \times 25 \mathrm{~m}$, I fit a $13 \times 13$ cell grid over a given cell, A, in the DoD that over-approximates the distance at which cells are spatially autocorrelated. The covariance between cell $\mathrm{A}$ and the cells outside the $13 \times 13$ cell grid is equal to 0 . The semivariance value at every distance from cell A to the center of every cell within the $13 \times 13$ cell grid was extracted from the semivariogram fit above and these were subtracted from $p$ in order to attain the covariance values. The total error in bathymetric change for cell $\mathrm{A}$ is then the sum of the variance of cell $\mathrm{A}$, $\delta A^{2}=\delta_{\Delta \hat{z}}{ }^{2}$, and the covariance values between cell A and cell $X_{i}$, every other cell in the $13 \times 13$ cell grid. This sum is multiplied by cell area and the number of cells following the same assumption of constant variance for each cell in the first method. Thus the uncertainty in volume accounting for spatial autocorrelation can be computed as follows in Equation 6:

$$
\delta V o l=\operatorname{Cell} \text { Area } * \sqrt{\operatorname{npix}\left(\delta A^{2}+\sum_{i=1}^{13^{2}} \operatorname{COV}\left(A, X_{i}\right)\right)}
$$

Table 2 summarizes the calculated $V_{\text {Erosion }}, V_{\text {Deposition, }}$ and $\delta V o l$ accounting for spatial autocorrelation for all volume calculations where $\sum_{i=1}^{13^{2}} \operatorname{COV}\left(A, X_{i}\right)=3.36 \mathrm{~m}$ in Equation 6 . 
Table 2. Volumetric change calculations following Equation 1 and uncertainty estimates, $\delta \mathrm{Vol}$, following Equation 6.

\begin{tabular}{|c|c|c|}
\hline \multicolumn{3}{|c|}{ Net Volume Change $\left(V_{\text {Erosion }}+V_{\text {Deposition }}\right)$ and $\delta V o l$} \\
\hline Total Area & Net Volume Change $\left(\mathrm{m}^{3}\right)$ & $\delta \mathrm{Vol}\left(\mathrm{m}^{3}\right)$ \\
\hline Survey Area $\left(75.90 \mathrm{~km}^{2}\right)$ & $-5,460,837$ & $\pm 399,518$ \\
\hline Gadwall $\left(24.09 \mathrm{~km}^{2}\right)$ & $-3,952,830$ & $\pm 225,062$ \\
\hline Main $\left(\mathbf{1 0 . 7 5} \mathrm{km}^{2}\right)$ & $-1,416,572$ & $\pm 150,370$ \\
\hline Greg $\left(10.29 \mathrm{~km}^{2}\right)$ & $-1,382,988$ & $\pm 147,132$ \\
\hline Pintail $\left(6.75 \mathrm{~km}^{2}\right)$ & $-587,580$ & $\pm 119,179$ \\
\hline East $\left(5.93 \mathrm{~km}^{2}\right)$ & $-15,125$ & $\pm 111,622$ \\
\hline Mallard $\left(12.89 \mathrm{~km}^{2}\right)$ & 995,686 & $\pm 164,627$ \\
\hline Campground $\left(5.20 \mathrm{~km}^{2}\right)$ & 898,572 & $\pm 104,583$ \\
\hline \multicolumn{3}{|c|}{ Negative Volume Change $\left(V_{\text {Erosion }}\right)$ and $\delta V o l$} \\
\hline Total Eroded Area & $\begin{array}{l}\text { Negative Volume Change } \\
\left(\mathbf{m}^{3}\right)\end{array}$ & $\delta \operatorname{Vol}\left(\mathrm{m}^{3}\right)$ \\
\hline Survey Area $\left(49.26 \mathrm{~km}^{2}\right)$ & $-11,865,891$ & $\pm 321,848$ \\
\hline Gadwall $\left(18.94 \mathrm{~km}^{2}\right)$ & $-4,790,420$ & $\pm 199,570$ \\
\hline Main $\left(8.34 \mathrm{~km}^{2}\right)$ & $-1,902,602$ & $\pm 132,446$ \\
\hline Greg $\left(7.81 \mathrm{~km}^{2}\right)$ & $-1,950,324$ & $\pm 128,169$ \\
\hline Pintail $\left(4.54 \mathrm{~km}^{2}\right)$ & $-1,223,803$ & $\pm 97,655$ \\
\hline East $\left(3.06 \mathrm{~km}^{2}\right)$ & $-656,036$ & $\pm 80,225$ \\
\hline Mallard $\left(4.92 \mathrm{~km}^{2}\right)$ & $-978,872$ & $\pm 101,742$ \\
\hline Campground $\left(1.65 \mathrm{~km}^{2}\right)$ & $-363,833$ & $\pm 58,860$ \\
\hline \multicolumn{3}{|c|}{ Positive Volume Change $\left(V_{\text {Deposition }}\right)$ and $\delta V o l$} \\
\hline Total Deposited Area & $\begin{array}{l}\text { Positive Volume Change } \\
\left(\mathbf{m}^{3}\right)\end{array}$ & $\delta \operatorname{Vol}\left(\mathrm{m}^{3}\right)$ \\
\hline Survey Area $\left(26.64 \mathrm{~km}^{2}\right)$ & $6,405,054$ & $\pm 236,703$ \\
\hline Gadwall $\left(5.15 \mathrm{~km}^{2}\right)$ & 837,590 & $\pm 104,041$ \\
\hline Main $\left(2.41 \mathrm{~km}^{2}\right)$ & 486,031 & $\pm 71,199$ \\
\hline Greg $\left(2.48 \mathrm{~km}^{2}\right)$ & 567,336 & $\pm 72,252$ \\
\hline Pintail $\left(2.22 \mathrm{~km}^{2}\right)$ & 636,223 & $\pm 68,316$ \\
\hline East $\left(2.86 \mathrm{~km}^{2}\right)$ & 640,911 & $\pm 77,611$ \\
\hline Mallard $\left(7.97 \mathrm{~km}^{2}\right)$ & $1,974,558$ & $\pm 129,424$ \\
\hline Campground $\left(3.55 \mathrm{~km}^{2}\right)$ & $1,262,405$ & $\pm 86,447$ \\
\hline
\end{tabular}




\section{References}

Allen, Y. C., Couvillion, B. R., \& Barras, J. A. (2012). Using Multitemporal Remote Sensing Imagery and Inundation Measures to Improve Land Change Estimates in Coastal Wetlands. Estuaries and Coasts, 35(1), 11. https://doi.org/10.1007/s12237-011-9437-z

Bevington, A., Twilley, R., Sasser, C., \& Holm, J., Guerry. (2017). Contribution of river floods, hurricanes, and cold fronts to elevation change in a deltaic floodplain, northern Gulf of Mexico, USA. Estuarine, Coastal and Shelf Science, 191. https://doi.org/10.1016/j.ecss.2017.04.010

Cahoon, D., White, D., \& Lynch, J. (2011). Sediment infilling and wetland formation dynamics in an active crevasse splay of the Mississippi River delta. Geomorphology, 131, 57-68. https://doi.org/10.1016/j.geomorph.2010.12.002

Carle, M. V., Sasser, C. E., \& Roberts, H. H. (2013). Accretion and Vegetation Community Change in the Wax Lake Delta Following the Historic 2011 Mississippi River Flood. Journal of Coastal Research, 569-587. https://doi.org/10.2112/JCOASTRES-D-1300109.1

Edmonds, D. A., Paola, C., Hoyal, D., \& Sheets, B. A. (2011). Quantitative metrics that describe river deltas and their channel networks. Journal of Geophysical Research: Earth Surface, 116(F4). https://doi.org/10.1029/2010JF001955

Edmonds, D. A., \& Slingerland, R. L. (2007). Mechanics of river mouth bar formation: Implications for the morphodynamics of delta distributary networks. Journal of Geophysical Research: Earth Surface, 112(F2). https://doi.org/10.1029/2006JF000574

Edmonds, D. A., \& Slingerland, R. L. (2008). Stability of delta distributary networks and their bifurcations. Water Resources Research, 44(9). https://doi.org/10.1029/2008WR006992

Espedal, H. A., Johannessen, O. M., \& Knulst, J. (1995). Natural films in coastal waters. In Geoscience and Remote Sensing Symposium, 1995. IGARSS '95. "Quantitative Remote Sensing for Science and Applications", International (Vol. 3, pp. 2106-2108 vol.3). https://doi.org/10.1109/IGARSS.1995.524121

Folse, T. M., Sharp, L. A., West, J. L., Hymel, M. K., Troutman, P., McGinnis, T. E., ... Miller, C. M. (2014). A STANDARD OPERATING PROCEDURES MANUAL FOR THE COASTWIDE REFERENCE MONITORING SYSTEM-WETLANDS:, 228.

Gagliano, S. M. (2003). Active Geological Faults and Land Change in SE LA. Coastal Environments, Incorporated. Retrieved from file:///C:/Users/Shawgroup/Downloads/1104310Active_Geological_Faults_and_Land_Change_in_SE_LA_Part_1.pdf

Hanegan, K., \& Georgiou, I. (2015). Tidal modulated flow and sediment flux through Wax Lake Delta distributary channels: Implications for delta development. In Proceedings of the 
International Association of Hydrological Sciences (Vol. 367, pp. 391-398). Copernicus GmbH. https://doi.org/10.5194/piahs-367-391-2015

Heyman, W. D., Ecochard, J.-L. B., \& Biasi, F. B. (2007). Low-Cost Bathymetric Mapping for Tropical Marine Conservation-A Focus on Reef Fish Spawning Aggregation Sites. Marine Geodesy, 30(1-2), 37-50. https://doi.org/10.1080/01490410701295996

Hiatt, M., \& Passalacqua, P. (2015). Hydrological connectivity in river deltas: The first-order importance of channel-island exchange. Water Resources Research, 51(4), 2264-2282. https://doi.org/10.1002/2014WR016149

Hiatt, M. R. (2013). A network-based analysis of river delta surface hydrology : an example from Wax Lake Delta. Retrieved from https://repositories.lib.utexas.edu/handle/2152/22850

Jankowski, K. L., Törnqvist, T. E., \& Fernandes, A. M. (2017). Vulnerability of Louisiana's coastal wetlands to present-day rates of relative sea-level rise. Nature Communications, 8, 14792. https://doi.org/10.1038/ncomms14792

Kim, W., Mohrig, D., Twiley, R., Paola, C., \& Parker, G. (2011). Is It Feasible to Build New Land in the Mississippi River Delta? Eos, Transactions American Geophysical Union, 90(42), 373-374. https://doi.org/10.1029/2009EO420001

Mossa, J. (2016). The changing geomorphology of the Atchafalaya River, Louisiana: A historical perspective. Geomorphology, 252, 112-127. https://doi.org/10.1016/j.geomorph.2015.08.018

Olliver, E. A., \& Edmonds, D. A. (2017). Defining the ecogeomorphic succession of land building for freshwater, intertidal wetlands in Wax Lake Delta, Louisiana. Estuarine Coastal and Shelf Science, 196, 45-57. https://doi.org/10.1016/j.ecss.2017.06.009

Roberts, H. H., Adams, R. D., \& Cunningham, R. H. W. (1980). Evolution of Sand-Dominant Subaerial Phase, Atchafalaya Delta, Louisiana. AAPG Bulletin, 64(2), 264-279.

Rosen, T., \& Xu, Y. J. (2013). Recent decadal growth of the Atchafalaya River Delta complex: Effects of variable riverine sediment input and vegetation succession. Geomorphology, 194, 108-120. https://doi.org/10.1016/j.geomorph.2013.04.020

Shaw, J. B., Estep, J. D., Whaling, A. R., Sanks, K. M., \& Edmonds, D. A. (2018). Measuring Subaqueous Progradation of the Wax Lake Delta with a Model of Flow Direction Divergence. Earth Surface Dynamics Discussions, 1-22. https://doi.org/10.5194/esurf2018-47

Shaw, J. B., \& Mohrig, D. (2014). The importance of erosion in distributary channel network growth, Wax Lake Delta, Louisiana, USA. Geology, 42(1), 31-34. https://doi.org/10.1130/G34751.1 
Shaw, J. B., Mohrig, David, \& Wagner, R. W. (2016). Flow patterns and morphology of a prograding river delta. Journal of Geophysical Research: Earth Surface, 121(2), 372391. https://doi.org/10.1002/2015JF003570

Shields, M. R., Bianchi, T. S., Mohrig, D., Hutchings, J. A., Kenney, W. F., Kolker, A. S., \& Curtis, J. H. (2017). Carbon storage in the Mississippi River delta enhanced by environmental engineering. Nature Geoscience, 10(11), 846-851. https://doi.org/10.1038/ngeo3044

Walker, N. D., \& Hammack, A. B. (2000). Impacts of Winter Storms on Circulation and Sediment Transport: Atchafalaya-Vermilion Bay Region, Louisiana, U.S.A. Journal of Coastal Research, 16(4), 996-1010. 